Krzysztof Kołodziejczyk

https://orcid.org/0000-0002-3262-311X

Uniwersytet Wrocławski

Wydział Nauk o Ziemi i Kształtowania Środowiska

Zakład Geografii Regionalnej i Turystyki

krzysztof.kolodziejczyk@uwr.edu.pl

\title{
MIĘDZY ELITARNOŚCIĄ I EGALITARYZMEM - W POSZUKIWANIU WŁAŚCIWEGO CHARAKTERU PRODUKTU TURYSTYCZNEGO ZABYTKOWEJ LINII TRAMWAJOWEJ WE WROCŁAWIU
}

\begin{abstract}
Abstrakt: Zabytkowa Linia Tramwajowa jest jedną z atrakcji turystycznych Wrocławia. Stanowi formę wykorzystania dużej i różnorodnej kolekcji wiekowych tramwajów, które obrazują rozwój komunikacji miejskiej w stolicy Dolnego Śląska czy - w szerszym ujęciu - w Europie Środkowej. Choć linia funkcjonuje już od 2009 r., to w ostatnich latach w ofercie wprowadzane są duże modyfikacje, m.in. zwiększenie liczby tras, dodanie komentarza przewodnika, dywersyfikacja zabytkowego taboru czy zmiany w taryfie. Celem artykułu jest ocena tych działań pod kątem zainteresowania turystów. Przeanalizowano statystyki dotyczące frekwencji i sprzedaży biletów w sezonie turystycznym w 2019 r. i porównano je z danymi z poprzedniego roku, mając na uwadze zwiększenie dostępności oferty poprzez wyraźne obniżenie cen biletów i zaplanowanie dużej liczby przystanków, co przynajmniej częściowo upodobniło Zabytkową Linię Tramwajową do linii zwykłych. Wprowadzone zmiany skutkowały wyraźnie większą liczbą pasażerów, ale mniejszymi przychodami, a także pewnymi problemami o charakterze organizacyjnym, jak np. zapewnienie odpowiedniej jakości obsługi przewodnickiej przy odbywającej się co chwila wymianie pasażerów. Rozważania prowadzone są w kontekście sposobów kształtowania produktu turystycznego.
\end{abstract}

Słowa kluczowe: zabytki techniki, zabytkowe tramwaje, transport w turystyce, linie turystyczne, produkt turystyczny, Wrocław.

\section{WSTĘP}

Zabytkowa Linia Tramwajowa (ZLT) funkcjonuje we Wrocławiu od 2009 r. i można ją uznać za produkt turystyczny o ugruntowanej pozycji, choć ciągle nie w pełni ukształtowany. Wpływają na to ograniczenia o charakterze formalnym (brak możliwości sprzedawania pamiątek spowodowany faktem, że linia jest uruchamiana na zlecenie gminy Wrocław ze środków publicznych) i finansowym (ograniczanie funduszy w kolejnych latach funkcjonowania, w związku z czym charakter linii zmieniał się z całorocznego na sezonowy i różnił się w poszczególnych latach częstotliwością i okresem kursowania). Ponieważ w ostatnich latach sezon kursowania ZLT nie zaczynał się zawsze w tym samym terminie (czasem początek maja, a innym razem połowa czerwca), utrudniona jest jej promocja, którą za każdym razem trzeba prowadzić od nowa i w oderwaniu od roku poprzedniego. Bardzo różny charakter mają też zmiany wprowadzane w ofercie. Z jednej strony wydaje się, że część modyfikacji nadaje jej elitarny charakter, jak np. wyraźny wzrost cen w 2018 r. i coraz częstsza obecność przewodników. Z drugiej strony z roku na rok zwiększane są liczby kursów i przystanków na trasie, co czyni ofertę bardziej dostępną. W 2019 r. - w przeciwieństwie do poprzedniego roku - ceny biletów zrównano z opłatami za przejazd zwykłymi środkami komunikacji miejskiej, więc w praktyce Zabytkową Linią Tramwajową mogli jechać także wrocławianie udający się po prostu do pracy lub na spotkanie - oferta nabrała więc bardziej paraturystycznego niż turystycznego charakteru ${ }^{1}$. W artykule przeanalizowano te w zasadzie wykluczające się zmiany, oceniono ich wpływ na popularność oferty i wskazano możliwe kierunki dalszego jej rozwoju.

Zabytkową Linię Tramwajową należy rozpatrywać w kategorii atrakcji turystycznej, o czym świadczy m.in. rosnąca frekwencja turystów. ZLT wpisuje się 
więc w popularne definicje tego pojęcia, podkreślające, że atrakcja musi zaciekawiać turystów i skłaniać ich do opuszczenia domu (Lew, 1987; Lundberg, 1985; Nowacki, 1999). Wśród atrakcji turystycznych często wymieniane są właśnie interesujące środki transportu (np. statki). Nieco problematyczne jest jednak przypisanie Zabytkowej Linii Tramwajowej do poszczególnych kategorii atrakcji turystycznych, np. zgodnie z klasyfikacją Swarbrooke'a i Page'a (2001, zob. także: Kruczek, 2011). Jakkolwiek same historyczne wagony zostały stworzone przez człowieka w innym celu niż przyciaganie turystów, to linia powstała w celach typowo turystycznych. Podobnie sytuacja ma się w przypadku definicji Cohena (1972), który dzieli atrakcje na rzeczywiste i sztuczne. Zabytkowa Linia Tramwajowa posiada swoją formę organizacyjną (wprawdzie ulega ona pewnym zmianom, ale jej trzon jest stały), nie działa jednak przez cały rok, co przez niektórych autorów wskazywane jest jako warunek konieczny uznania czegoś za atrakcję turystyczną (Nowacki, 2014). Ujęcia definicyjne różnią się jednakże od siebie, a trzeba podkreślić, że analizowana oferta jest obecna na rynku już od ponad dekady, funkcjonując przez znaczną część roku. Zabytkowe tramwaje stanowią jednocześnie część dziedzictwa kulturowego (lub w węższym ujęciu-dziedzictwa techniki), które może stać się atrakcją turystyczną czy elementem produktu turystycznego (Nowacki, 1999).

Analizowane tu zagadnienia wpisują się więc także w problematykę rozwoju produktów turystycznych (Kaczmarek, Stasiak, Włodarczyk, 2010; Smith, 1994; Stasiak, 2013), gdyż mamy do czynienia z atrakcją odpowiednio zarządzaną w celu zapewnienia rozrywki i edukacji (Middleton, 1996; Nowacki, 1999, 2012, 2014). Spośród poszczególnych rodzajów produktów turystyczną linię komunikacji zbiorowej (w tym obsługiwaną zabytkowym taborem) można traktować jako prosty produkt-usługę (usługą jest zapewnienie transportu), ale także jako najbardziej złożony produkt-szlak (Stasiak, 2006, 2007; zob. też: Kołodziejczyk, 2014a; Mikos von Rohrscheidt, 2010; Styperek, 2002). W drugim z wymienionych przypadków musi być spełniony warunek, że poza samym przejazdem oferowane są dodatkowe elementy, np. usługi przewodnika, sprzedaż pamiątek czy efekty różnego typu współpracy z obiektami (atrakcjami) turystycznymi, które taka linia łączy. Mogą one być powiązane z tematyką motoryzacji, dziedzictwa techniki lub współczesnych osiągnięć człowieka w zakresie transportu ${ }^{2}$ albo stanowić przegląd walorów danej miejscowości, których wspólnym mianownikiem jest po prostu to, że są spajane przez trasę danej linii. W takim szerokim ujęciu linia turystyczna odznacza się właściwie wszystkimi cechami produktu-szlaku (Kaczmarek, Stasiak, Włodarczyk, 2010; Stasiak, 2006), tj.: zdeterminowaniem przestrzennym (trasa linii wynika z możliwości jej wyznaczenia, czyli m.in. przebiegu i dostępności torów tramwajowych, ale także powinna nawiązywać - w miarę możliwości - do rozmieszczenia walorów turystycznych), złożonością (stanowi konglomerat produktów prostych ${ }^{3}$ ), multiwytwarzalnością (wielu twórców/producentów pojedynczych dóbr i usług), synergicznością (powiązanie wielu atrakcji na konkretnej trasie w jedna, kompleksową ofertę).

Cechami spajającymi elementy takiego produktu są: sposób przemieszczania się (np. zabytkowym tramwajem lub autobusem), motywy (chęć poznania najważniejszych atrakcji danego miasta w interesujący sposób / w krótkim czasie), ewentualnie tematyka (jeśli w jakiś konkretny sposób dobrano atrakcje na trasie). By taki produkt mógł się rozwijać, oprócz jego komercjalizacji niezbędne jest także odpowiednie zarządzanie nim (Bąk, 1999; Mikos von Rohrscheidt, 2010). Sposoby realizacji tych założeń mogą być różne - od próby trafienia do jak najszerszego grona odbiorców, poprzez zapewnienie jak największej dostępności (kierunek egalitarny ${ }^{4}$ ), do podejmowania działań mających na celu stworzenie produktu elitarnego (w tym przypadku turyści będą skłonni więcej zapłacić za unikatowe doświadczenia). Istotna jest tzw. wartość dodana, czyli zapewnienie odbiorcom dodatkowych korzyści w sferze psychologicznej (emocje, satysfakcja, zadowolenie, poczucie prestiżu lub wyjątkowości - por. Stasiak, 2006), co dość łatwo może być zrealizowane przez obcowanie z dawnymi pojazdami komunikacji miejskiej, którymi podróżowano np. sto lat temu, i oczywiście korzystanie z nich. Kreowanie wyobrażeń o produkcie turystycznym w dużym stopniu wynika z działań marketingowych (Bąk, 1999), ale wpływają na nie także fizyczne cechy oferty (np. sposób obsługi, forma i jakość materiałów promocyjnych).

Zabytkowa Linia Tramwajowa czy inne turystyczne linie obsługiwane zabytkowymi pojazdami były dotychczas analizowane jako specyficzna forma transportu zbiorowego (Kołodziejczyk, 2019; por. Mehring, 2017; Meyer, 2009, 2011, 2015) oraz sposób wykorzystania i utrzymania zabytkowego taboru (Kołodziejczyk, 2011, 2018; por. Kucharski, Kikin, 2010), lub też w kontekście poszczególnych rodzajów turystyki, głównie miejskiej, i dziedzictwa (Kołodziejczyk, 2019; por. Ashworth, 1992; Kowalczyk, 2005; Lipińska, 2011; Matczak, 1989; Mikos von Rohrscheidt, 2008; Page, 1995). Analizy te jednak są jak dotąd nieliczne. Zagadnienie pojazdów (w tym zabytkowych) traktowanych jako walory krajoznawcze jest jednak obecne w dyskursie naukowym, chociażby o turystyce motoryzacyjnej. Ten rodzaj turystyki można zdefiniować jako podróże, których celem i motywacją jest odwiedzanie miejsc związanych z motoryzacją, ważnych dla jej rozwoju, takich jak: muzea motoryzacji, fabryki samochodowe, eventy o tej tematyce (Cudny, 2018; Cudny, Horňák, 2016; Cudny, Jolliffe, 2019; Dolles, Dibben, Hardy, 2018; zob. też: Coles, 2004, 2008). O rosnącym znaczeniu tego rodzaju podróży świadczy 
duża popularność zlotów i festiwali motoryzacyjnych czy rajdów zabytkowych samochodów (tylko w Polsce odbywa się kilkaset tego typu wydarzeń rocznie, choć ich wielkość i zasięg są bardzo zróżnicowane), ale również zainteresowanie badaczy (Cegielski, Mules, 2002; Cudny, 2018; Prideaux, Carson, 2011). Zabytkowa Linia Tramwajowa wpisuje się także $\mathrm{w}$ trend nadawania funkcji turystycznych obiektom zabytkowym (Pawlikowska-Piechotka, 2009), choć zdecydowanie częściej dotyczy to zabytków nieruchomych, np. dworów, kamienic, zamków, pałaców czy klasztorów, ale też obiektów poprzemysłowych i zabytków techniki (zob. np. Cudny, 2016; Jędrysiak, 2011; Kołakowski, 2010; Nitkiewicz-Jankowska, 2006; Widawski, Duda-Seifert, 2014; Wójcik, 2012).

Celem artykułu jest ocena zmian wprowadzonych w ofercie Zabytkowej Linii Tramwajowej w ostatnich latach z perspektywy zainteresowania nią turystów. W tym celu przeanalizowane zostały dane z 2019 r. dotyczące frekwencji i przychodów z biletów, po czym zestawiono je $\mathrm{z}$ informacjami $\mathrm{z}$ poprzedniego roku w celu określenia, jaki wpływ miała ewolucja oferowanego produktu turystycznego. Uzyskane dane były na tyle szczegółowe (w podziale na poszczególne kursy i konkretne typy biletów), że pozwoliły na uchwycenie zmian $w$ kolejnych dniach funkcjonowania linii w miarę upływu czasu, kiedy oferta była dostępna dla wrocławian i turystów. Można bowiem zakładać, że dzięki akcji promocyjnej i regularnemu pojawianiu się zabytkowych tramwajów w przestrzeni miasta rosła świadomość istnienia oferty, a w konsekwencji częstość korzystania z niej. Informacje pochodzą od dwóch z trzech przewoźników organizujących przejazdy Zabytkową Linią Tramwajową w 2019 r. i od obu przewoźników odpowiedzialnych za kursy w 2018 r. Nieuwzględnienie w badaniach trzeciego przewoźnika z 2019 r. wynika $z$ innych zasad jego funkcjonowania i dłuższego okresu jeżdżenia, w związku z czym branie pod uwagę tych danych zaburzyłoby wyniki. Prace kameralne polegały na analizie statystycznej pozyskanych danych i ich wizualizacji w programie Microsoft Excel. W efekcie możliwe było porównanie wyników z 2019 i 2018 r. oraz wskazanie pożądanych kierunków rozwoju produktu turystycznego. Artykuł stanowi kontynuację publikacji poświęconej analizie funkcjonowania Zabytkowej Linii Tramwajowej w 2018 r. (Kołodziejczyk, 2019).

\section{ZMIANY W OFERCIE ZABYTKOWEJ LINII TRAMWAJOWEJ W LATACH 2016-2019}

Produkt Zabytkowej Linii Tramwajowej we Wrocławiu od 2016 r. ulega ewolucji zgodnie z decyzjami działów merytorycznych Urzędu Miejskiego Wrocławia
(Biuro Promocji Miasta i Turystyki, a od 2019 r. Wydział Partycypacji Społecznej), częściowo w porozumieniu z przewoźnikami. Przez wiele lat linia kursowała tylko z centrum miasta do Hali Stulecia na wschodzie, natomiast w 2016 r. zdywersyfikowano trasy, wprowadzając dodatkowo przejazdy wyłącznie po Starym Mieście. W tym okresie pojawiły się także wybrane kursy z usługą przewodnicką. Duże zmiany nastąpiły w 2018 r., kiedy linia funkcjonowała w weekendy ${ }^{5}$ od 16 czerwca do 9 września. Dotąd linia była obsługiwana wyłącznie przez Towarzystwo Miłośników Wrocławia (TMW), natomiast od $2018 \mathrm{r}$. operatorem stało się konsorcjum stowarzyszeń ${ }^{6}$, do którego poza TMW wszedł Klub Sympatyków Transportu Miejskiego (KSTM). Pozwoliło to na większe zróżnicowanie taboru kursującego na linii, w tym na uwzględnienie tramwaju Konstal 102Na z 1972 r., jako że wówczas zakończył się jego kilkuletni kompleksowy remont. W 2018 r. zabytkowe pojazdy kursowały na czterech trasach: A i B, obsługiwanych przez KSTM, tradycyjnie łączących operę i Halę Stulecia (trzy pary kursów), oraz C i D, na których tramwaje TMW jeździły po centrum miasta, wykonując odpowiednio cztery i jeden kurs (rys. 1). Tak jak w $2017 \mathrm{r}$. trasę D, tzw. nocna, poprowadzono w taki sposób, by pokazać najciekawsze z iluminowanych zabytków. Wyznaczona godzina (20.00) okazała się jednak przez większą część sezonu zbyt wczesna, by turyści mogli zobaczyć podświetlone obiekty. Dużą zmianą było wprowadzenie kilkunastu przystanków na trasach A i B w pobliżu ważniejszych atrakcji turystycznych. Pozwoliło to na realizację przewozów na zasadzie hop on - hop off (wsiadania i wysiadania), co jest rozwiązaniem często i z powodzeniem stosowanym w wielu miastach na Zachodzie i w Polsce, ale dotąd nie było wykorzystywane we Wrocławiu ${ }^{7}$. Wymusiło to jednak potrzebę zapewnienia w wagonach KSTM obsługi konduktorskiej, która jest organizowana na zasadach wolontariatu.

W 2018 r. wprowadzono też dodatkowe rodzaje biletów (powrotne i rodzinne), co było odpowiedzią obu przewoźników na podwyższenie przez gminę Wrocław ceny biletów jednorazowych (8 zł normalny i 4 zł ulgowy), która została narzucona w ogłoszeniu konkursowym na obsługę linii (przewoźnikom zostawiono jednak możliwość zaproponowania dodatkowych typów biletów wraz z cenami). Nowe rodzaje biletów miały na celu obniżenie kosztów podróży łącznie na trasach A i B (bilety powrotne) oraz na wszystkich trasach dla rodzin. Niestety ze względu na potrzebę osobnych rozliczeń przez oba stowarzyszenia nie było możliwości wprowadzenia biletów jednodniowych, ważnych w pojazdach obu przewoźników. Na wszystkich trasach podczas wybranych kursów oferowano komentarz przewodnika. W tym roku również Miejskie Przedsiębiorstwo Komunikacyjne sp. z o.o. we Wrocławiu (MPK) po raz pierwszy uruchomiło na przełomie czerwca i lipca Linię 

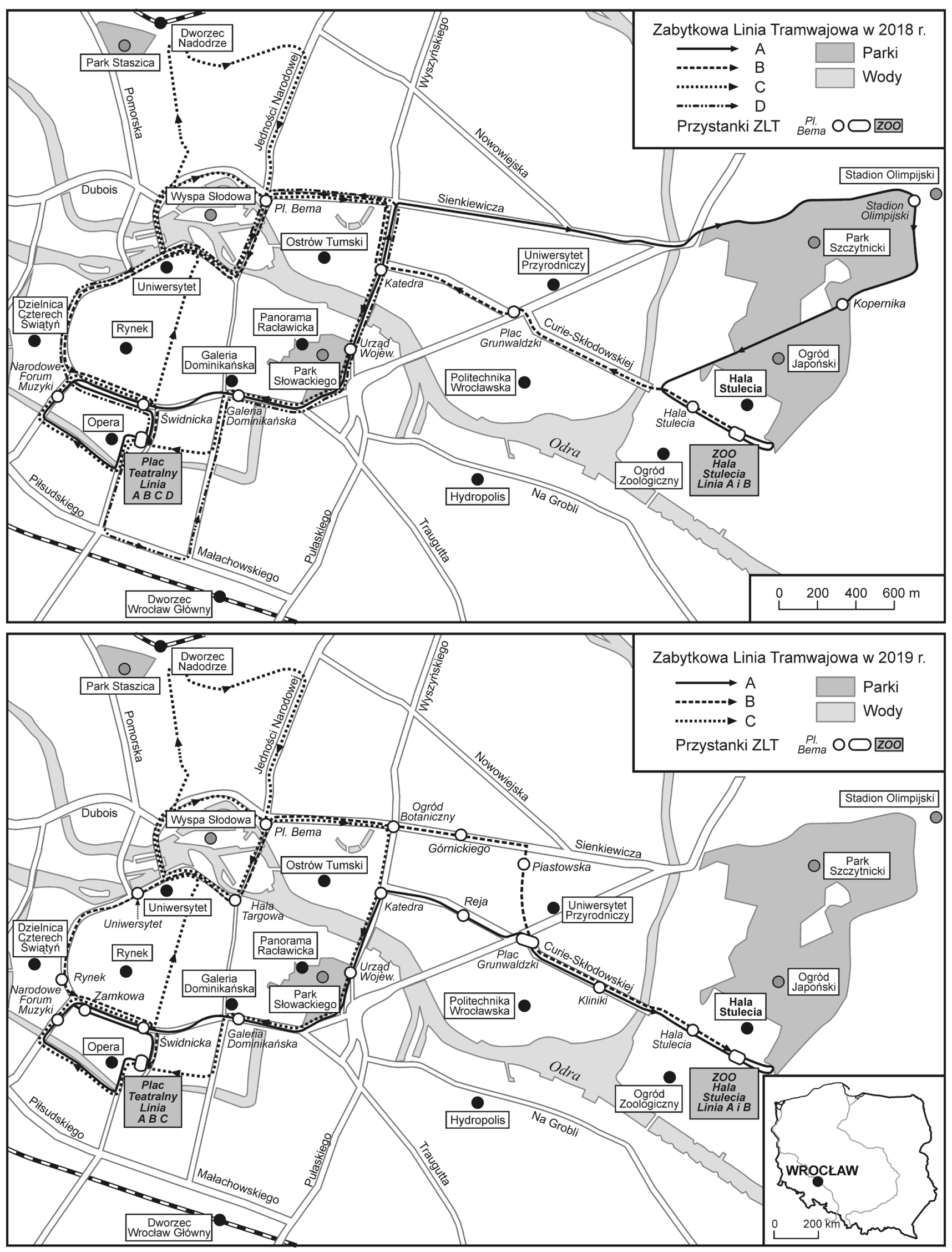

Rysunek 1. Schemat tras Zabytkowej Linii Tramwajowej w 2018 i 2019 r. Uwagi: Trasa C nie uległa zmianie, trasa D w 2019 r. nie funkcjonowała. Źródło: opracowanie własne 
Tabela 1. Formy dziedzictwa związanego z transportem zbiorowym w ofercie turystycznej i kulturalnej Wrocławia

\begin{tabular}{|c|c|}
\hline Forma & Charakterystyka \\
\hline $\begin{array}{l}\text { Regularna linia turystyczna obsługiwana } \\
\text { zabytkowymi tramwajami }\end{array}$ & $\begin{array}{l}\text { Zabytkowa Linia Tramwajowa obsługiwana kilkoma wagonami kursuje co roku } \\
\text { w sezonie letnim. }\end{array}$ \\
\hline $\begin{array}{l}\text { Linie okazjonalne dowożące na różne } \\
\text { wydarzenia i do obiektów kulturalnych }\end{array}$ & $\begin{array}{l}\text { Zabytkowe tramwaje i autobusy kursują w różnym wymiarze czasu w ramach } \\
\text { współpracy z władzami miejskimi, instytucjami kultury i firmami. Największy } \\
\text { zakres usług odnotowuje się podczas Nocy Muzeów, kiedy uruchamianych jest } \\
\text { kilka linii. Pojazdy dowoziły już wrocławian i turystów m.in. na otwarcie wystawy } \\
\text { w Pawilonie Czterech Kopuł koło Hali Stulecia (filia Muzeum Narodowego), na tor } \\
\text { wyścigów konnych na Partynicach, na odsłonięcie rzeźb w parku Wschodnim, na } \\
\text { wydarzenia organizowane przez Instytut Pamięci Narodowej. }\end{array}$ \\
\hline $\begin{array}{l}\text { Zabytkowe pojazdy komunikacji miejskiej } \\
\text { wykorzystywane podczas wydarzeń } \\
\text { kulturalnych }\end{array}$ & $\begin{array}{l}\text { Na pokładzie zabytkowych tramwajów dość regularnie występują muzycy jazzowi } \\
\text { (tzw. Jazz Tramwaj pojawiający się od } 2014 \mathrm{r} \text {.), a także inni artyści (raz takie } \\
\text { wydarzenie zorganizowano także w autobusie). Pojazdy stają się atrakcją wydarzeń } \\
\text { odbywających się w przestrzeni miejskiej (np. w ramach Europejskiego Tygodnia } \\
\text { Zrównoważonego Transportu). }\end{array}$ \\
\hline $\begin{array}{l}\text { Możliwość wynajęcia } \\
\text { zabytkowych pojazdów } \\
\text { komunikacji zbiorowej }\end{array}$ & $\begin{array}{l}\text { Wszystkie sprawne zabytkowe pojazdy można wynajmować na przejazdy } \\
\text { okolicznościowe, imprezy integracyjne itp. Istnieją sugerowane trasy przejazdu, ale } \\
\text { w zależności od potrzeb możliwa jest realizacja usługi na dowolnej trasie. Zabytkowe } \\
\text { tramwaje często są zamawiane jako atrakcyjny transport podczas ślubów. Istnieje } \\
\text { możliwość skorzystania z oferty przewodnika. }\end{array}$ \\
\hline $\begin{array}{l}\text { Udosteppnianie zajezdni tramwajowych } \\
\text { i autobusowych }\end{array}$ & $\begin{array}{l}\text { Co roku odbywa się Dzień Otwarty Zajezdni Popowice, podczas którego można } \\
\text { obejrzeć większość wiekowych tramwajów i autobusów oraz wybrane wnętrza } \\
\text { zabytkowej zajezdni, po których oprowadza przewodnik. Organizowane są wtedy } \\
\text { także przejażdżki po mieście i wykłady historyczne. Dodatkowa oferta związana jest } \\
\text { z wychowaniem komunikacyjnym i promowaniem zrównoważonego transportu. } \\
\text { Zajezdnia otwierana jest na mniejszą skalę kilka razy w roku (np. gdy odbywa się } \\
\text { Photoday). Co roku organizowany jest Dzień Otwarty MPK Wrocław, podczas } \\
\text { którego udostępniane są dwie zajezdnie (tramwajowa i autobusowa). W wydarzeniu } \\
\text { tym zabytkowe pojazdy komunikacji miejskiej również odgrywają ważną rolę. }\end{array}$ \\
\hline Sesje zdjęciowe i filmowe & $\begin{array}{l}\text { Możliwość urządzenia sesji z zabytkowymi pojazdami komunikacji zbiorowej } \\
\text { w przestrzeni miejskiej lub na terenie zajezdni. Wykorzystywane przez osoby } \\
\text { prywatne (np. sesje ślubne) i firmy (głównie podczas kręcenia filmów). }\end{array}$ \\
\hline
\end{tabular}

Źródło: opracowanie własne.

Turystyczną z jednym historycznym wagonem, także świeżo wyremontowanym, stanowiącą konkurencję dla Zabytkowej Linii Tramwajowej. Równolegle funkcjonowały więc dwie linie tramwajowe o charakterze turystycznym, obie finansowane $\mathrm{z}$ funduszy miejskich (ale przez różne działy), kursujące na podobnych trasach i w zbliżonych godzinach, przy czym na linii MPK obowiązywała zwykła taryfa miejska, o cenach biletów wyraźnie niższych niż w ZLT. Co ciekawe, nie wpłynęło to negatywnie na frekwencję na Zabytkowej Linii Tramwajowej, gdyż liczba korzystających z niej turystów wzrastała także po uruchomieniu Linii Turystycznej. Tramwaj historyczny MPK kursował też dłużej - do końca października, ale promocja tej oferty była ograniczona (tylko za pośrednictwem mediów społecznościowych; brak ulotek czy innych wiadomości w punktach informacji turystycznej).

W celu uniknięcia tej specyficznej konkurencji zmieniono formę Zabytkowej Linii Tramwajowej w 2019 r. Wchłonęła ona w zasadzie linię MPK. Całość była promowana jako jedna oferta, choć rozliczenia odbywały się osobno - kursy MPK z jednej strony oraz KSTM i TMW z drugiej były finansowane przez różne komórki Urzędu Miejskiego. Zasadniczą zmianą było wprowadzenie taryfy miejskiej, czyli rozwiązania wdrożonego już w 2018 r. na Linii Turystycznej. Pasażerowie Zabytkowej Linii Tramwajowej mogli korzystać ze wszystkich uprzednio zakupionych miejskich biletów papierowych, biletów zakodowanych na kartach miejskich lub innych nośnikach albo mogli nabyć bilety jednorazowe w zabytkowych tramwajach, ale w cenach zwykłych biletów komunikacji miejskiej. Jedynie tego rodzaju bilety były dostępne w pojazdach (jednorazowe normalne i ulgowe). Zrezygnowano z biletów rodzinnych i powrotnych, ale nie było to tak odczuwalne ze względu na wyraźną obniżkę stawek (przykładowo cena normalnego biletu jednorazowego spadła z 8 zł do 3,40 zł). Linia w 2019 r. funkcjonowała od 1 maja do 27 października w soboty, niedziele i święta, przy czym przez cały ten czas kursowało tylko MPK, oba stowarzyszenia zaś poszerzyły ofertę w okresie od 15 czerwca do 15 września. MPK wraz z KSTM obsługiwały trasy A i B, których przebieg uległ pewnemu skróceniu względem poprzedniego roku (rys. 1). Pierwszy podmiot wykonywał 
cztery pary kursów, drugi zaś - trzy, dzięki czemu w okresie wakacyjnym dostępnych było siedem par kursów (odjazdy spod opery co godzinę od 11.00 do 17.00). Tramwaje zatrzymywały się na wszystkich mijanych przystankach, co w połączeniu z taryfą uczyniło te trasy analogicznymi do regularnych linii, a usługa nabrała cech oferty paraturystycznej (por. Kowalczyk, Derek, 2010). Było to problematyczne podczas kursów z przewodnikiem, kiedy co chwila następowała wymiana pasażerów, którym należało sprzedać bilety lub je sprawdzić. Utrudniało to turystom odbiór treści, a przewodnikom nawiązanie kontaktu ze słuchaczami, pasażerowie dosiadający się na kolejnych przystankach po wejściu do tramwaju mogli wysłuchać wyłącznie rozpoczętej już narracji. W przypadku działań TMW w 2019 r. zrezygnowano z nocnej trasy D, w zamian wprowadzając piąty kurs na trasie C (wszystkie kursy były z przewodnikiem; odjazdy co godzinę od 13.30 do 17.30). W zakresie przystanków na trasie C utrzymano sytuację z poprzedniego roku - można było wsiąść tylko przy operze, nie było żadnych przystanków pośrednich. Pewne zamieszanie mogło wprowadzać to, że tramwaje obsługiwane przez TMW nie kursowały w święta, więc wtedy oferowane były przejazdy tylko na trasach A i B. Działania promocyjne podejmowali głównie członkowie KSTM, dlatego w praktyce rozpoczęły się one w połowie czerwca. Wcześniej linię w bardzo ograniczonym stopniu reklamowało MPK, właściwie tylko w swoich mediach społecznościowych. Dopiero po rozszerzeniu oferty przez stowarzyszenia pojawiły się ulotki promocyjne i broszury o treściach historycznych, dystrybuowane odpowiednio we wszystkich punktach informacji turystycznej w mieście oraz w tramwajach jako swoista pamiątka. Pojawiło się też więcej artykułów prasowych dotyczących Zabytkowej Linii Tramwajowej (np. Kokoszkiewicz, 2019; Krejner, 2019; Wolniewicz, 2019). Trzeba jednocześnie pamiętać, że Zabytkowa Linia Tramwajowa jest elementem dziedzictwa związanego z transportem zbiorowym obecnego w ofercie turystycznej i kulturalnej Wrocławia (tab. 1).

\section{FREKWENCJA I SPRZEDAŻ BILETÓW ZABYTKOWEJ LINII TRAMWAJOWEJ W 2019 R.}

W całym sezonie kursowania Zabytkowej Linii Tramwajowej w 2019 r. KSTM i TMW przewiozły łącznie 4493 pasażerów ${ }^{8}$, natomiast wartości dzienne zawierały się w przedziale od 73 (w pierwszym dniu sezonu) do 221 osób (w przedostatnią niedzielę sezonu) (rys. 2). Widoczny jest wzrost zainteresowania ofertą wraz z upływem czasu, co wiąże się z rozpowszechnianiem informacji o niej i coraz większą świadomością jej istnienia zarówno wśród osób zajmujących się zawodowo informacją turystyczną w mieście, jak i wśród wrocławian, którzy także stanowią ważną grupę pasażerów (wyjazdy na tereny rekreacyjne w parku Szczytnickim, pokazywanie miasta gościom). Najniższą frekwencję dzienną (mniej niż 100 osób) odnotowano w czerwcu, w tym w pierwszym i trzecim dniu kursowania linii (odpowiednio 73 i 77 pasażerów), natomiast najwyższą (ponad 200 osób) - od połowy sierpnia, przy czym aż dwukrotnie we wrześniu, w przedostatni weekend sezonu (201 i 221 osób w sobotę i niedzielę). W czerwcu i lipcu tylko jeden raz zdarzyło się, że ponad 150 pasażerów w ciągu jednego dnia skorzystało z ZLT, a trzy razy nie osiagnięto nawet liczby 100 osób. W tym okresie frekwencja najczęściej zawierała się w przedziale od 130 do 150 osób. Natomiast w sierpniu i we wrześniu tylko w jednym dniu liczba pasażerów nie była wyższa niż 150 osób, trzykrotnie przekroczyła wartość 200, a najczęściej zawierała się w przedziale między 165 a 185. Zjawisko wzrostu frekwencji proporcjonalnie do czasu obecności oferty na rynku potwierdziły dane z wrze-

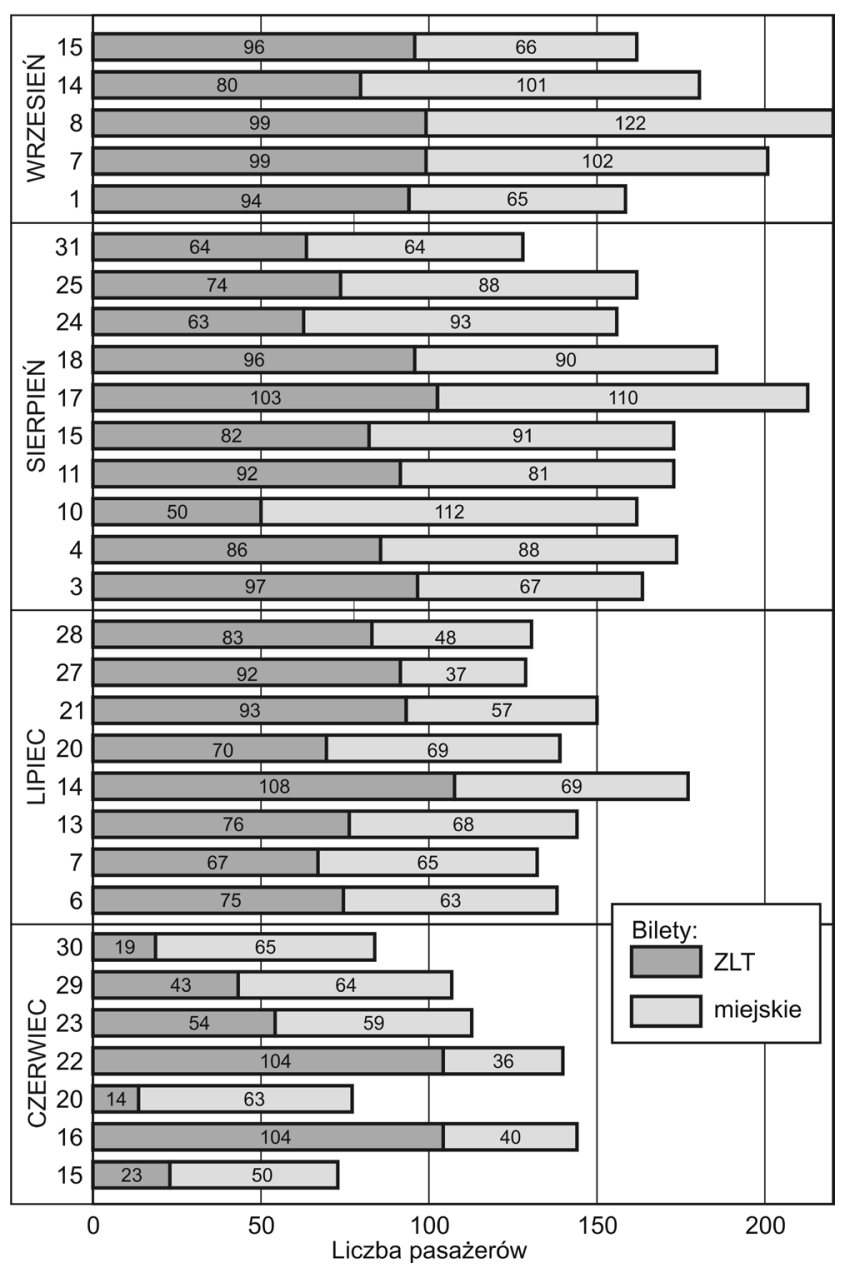

Rysunek 2. Liczba pasażerów

Zabytkowej Linii Tramwajowej w 2019 r.

w zależności od sposobu regulowania opłaty za przejazd Źródło: opracowanie własne 
śnia. Można było bowiem zakładać, że po zakończeniu wakacji liczba pasażerów zacznie spadać. Tak się jednak nie stało - średnio w tym miesiącu przewożono 185 pasażerów dziennie, podczas gdy w sierpniu było to 169 osób (dla porównania w czerwcu - 105, a w lipcu-143).

W całym sezonie KSTM i TMW zorganizowały 320 kursów zabytkowymi tramwajami i na każdy przypadło średnio ok. 14 pasażerów, co wydaje się wartością dość niską. Przy jej ocenie należy jednak wziąć pod uwage fakt, że wiekowe pojazdy komunikacji miejskiej nie są tak pojemne jak współczesne. Niektóre wagony, kursujące na linii w 2019 r., mają tylko 12 lub 16 miejsc siedzących (Lubka, Stiasny, 2010; Żurawicz, 2013), choć oczywiście jazda na stojąco jest możliwa (uwzględniając miejsca stojące, najmniej pojemny wagon może przewieźć ok. 30 osób). Najniższą średnią liczbę pasażerów $\mathrm{w}$ przeliczeniu na jeden przejazd osiągnięto $\mathrm{w}$ pierwszym dniu kursowania $(6,6)$, najwyższą zaś - 15 sierpnia $(28,8)$, przy czym na tę drugą wartość złożyły się dwa czynniki: po pierwsze długi weekend, a po drugie tego dnia tramwaje obsługiwane przez TMW nie jeździły, więc do dyspozycji była mniejsza liczba kursów ${ }^{9}$. Poza tym dniem, w którym obchodzone jest święto Wniebowzięcia NMP, najwyższą średnią frekwencję podczas kursu $(20,1)$ osiagnięto $\mathrm{w}$ przedostatnią niedzielę sezo$\mathrm{nu}$, co stanowi kolejne potwierdzenie dużego znaczenia września w ruchu turystyczno-rekreacyjnym. W żadnym innym dniu nie osiągnięto już wartości powyżej 20 osób. Dane o średniej liczbie pasażerów jadących jednym kursem wyliczone dla miesięcy są również potwierdzeniem wzrostu zainteresowania ofertą $\mathrm{w}$ miarę upływu czasu od jej pojawienia się na rynku (czerwiec $-10,4$ osoby, lipiec -13,0, sierpień -16,7, wrzesień -16,8).

Spośród ogółu pasażerów większość zakupiła bilety sprzedawane wyłącznie na przejazdy pojazdami Zabytkowej Linii Tramwajowej, ale przewaga była nieznaczna (51,19\%; por. rys. 5), co świadczy o tym, że wprowadzona w 2019 r. możliwość jazdy na podstawie biletów miejskich została doceniona zarówno przez wrocławian, jak i przez turystów (ci pierwsi posiadali najczęściej bilety długookresowe zakodowane na kartach miejskich, drudzy zaś - głównie papierowe bilety dobowe). W ciągu 30 dni obsługiwania Zabytkowej Linii Tramwajowej przez KSTM i TMW osoby korzystające z biletów miejskich przeważały przez 14 dni (rys. 2), przy czym $\mathrm{z}$ reguły była to przewaga niewielka (udział między 50 a $60 \%$ ogółu pasażerów). Odsetek powyżej $60 \%$ osiągnięto tylko czterokrotnie, przy czym aż trzy razy taki wynik odnotowano w czerwcu (a jeden w sierpniu), w tym najwyższą wartość ( $81,82 \%$ ) zarejestrowano 20 czerwca (gdy wykonywane były tylko kursy koordynowane przez KSTM) i drugą najwyższą (77,38\%) - 30 czerwca. Liczba pasażerów korzystających z zabytkowych tramwajów po zakupie biletów miejskich zwiększała się w trakcie sezonu (z pewnymi spadkami na przełomie lipca i sierpnia oraz sierpnia i września), ale o wzroście ogólnej frekwencji zdecydowała w dużym stopniu coraz większa liczba osób wykupujących bilety w zabytkowych tramwajach, choć podlegała ona znacznym wahaniom (rys. 2). Na podstawie biletów oferowanych przez ZLT w czerwcu każdego dnia tą linią jechały średnio 52 osoby, ale w tym miesiącu rozrzut wartości był największy - od 14 do 104 pasażerów (taka liczba, druga najwyższa w całym sezonie, została odnotowana w czerwcu aż dwukrotnie). W kolejnych miesiącach było to statystycznie 83, 81 i 94 pasażerów, a najwyższą wartość (108) osiągnięto 14 lipca. Trudno wskazać zależności między liczbami osób, które kupiły bilety miejskie i bilety sprzedawane $w$ tramwajach zabytkowych - czasem obniżenie się jednej wartości odpowiadało spadkowi drugiej (np. 31 sierpnia), a niekiedy zależność była odwrotna (np. 22 czerwca i 21 lipca). Zasadniczo największe wahania wartości odnotowano w czerwcu oraz na przełomie sierpnia i września.

Łączny przychód z biletów sprzedawanych w wagonach KSTM i TMW kursujących na Zabytkowej Linii Tramwajowej w 2019 r. wyniósł 6529,70 zł. Zdecydowana większość tych zarobków $(80,24 \%)$ pochodziła z dystrybucji biletów normalnych (rys. 3), co wynika z ich wyższej ceny, ale także większej liczby (sprzedano 2300 biletów, z czego 67\% normalnych). Mała liczba wykorzystanych biletów ulgowych wiązała się z zawężeniem grupy osób, którym one przysługuja, jako że z opłat zwolniono dzieci i uczącą się młodzież. W praktyce bilety ulgowe kupowali więc przede wszystkim emeryci i renciści. Zdarzały się jednak dni, kiedy liczba sprzedanych biletów ulgowych przewyższała liczbę pełnopłatnych (rys. 4). Taka sytuacja zdarzyła się w całym sezonie trzykrotnie (co ciekawe, w jego drugiej połowie; najwyższy odsetek to $60 \%$ ), a dodatkowo dwukrotnie sprzedano tylko nieznacznie mniej biletów ulgowych niż normalnych (udział powyżej $45 \%$ ). Wiąże się to zapewne $\mathrm{z}$ pojawieniem się $\mathrm{w}$ danym dniu większej

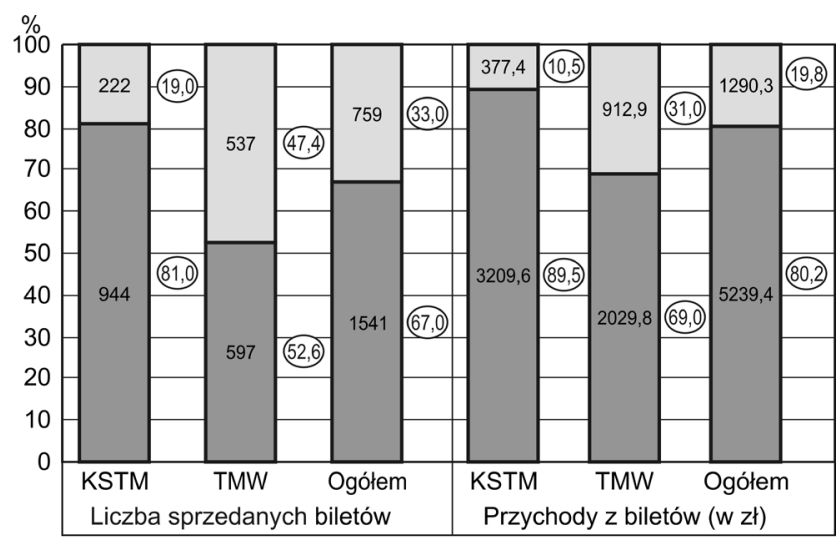

Bilety ulgowe

Bilety normalne

(19,0) Odsetek biletów

Rysunek 3. Struktura biletów sprzedanych w tramwajach kursujących na Zabytkowej Linii Tramwajowej w 2019 r. i wynikających z nich przychodów Źródło: opracowanie własne 


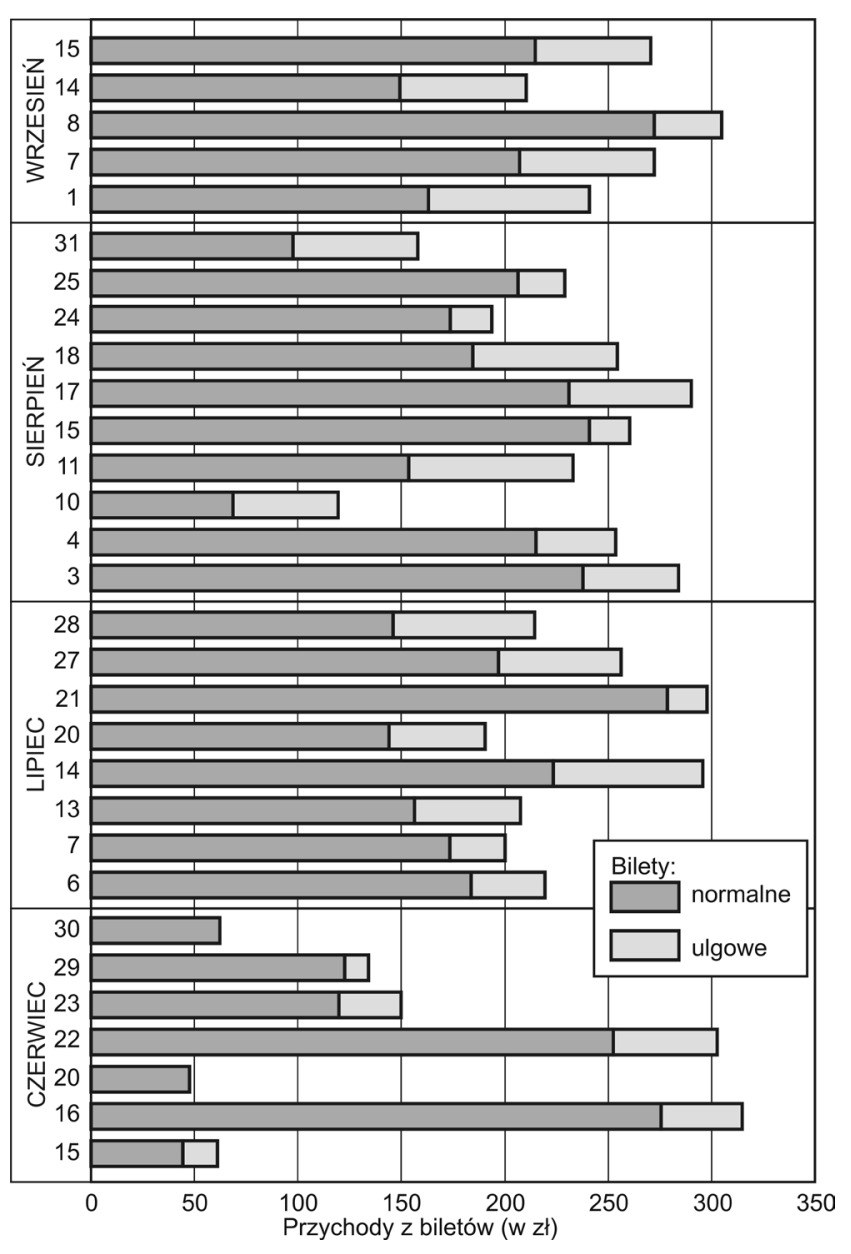

Rysunek 4. Przychody z biletów

Zabytkowej Linii Tramwajowej w 2019 r. Źródło: opracowanie własne

grupy (np. zorganizowanej) osób w starszym wieku. W inne dni udział biletów ulgowych zawierał się w przedziale 25-40\%, choć cechował się bardzo dużą zmiennością. Ponieważ bilety ulgowe kosztowały dwa razy mniej niż normalne, ich udział w przychodach był znacznie niższy - średnio w całym sezonie 19,76\%, przy czym w poszczególnych dniach ich odsetek wynosił od 0\% (20 czerwca) do 42,86\% (10 sierpnia), choć rzadko przekraczał 30\%. Ogólnie przychody z biletów ulegały w całym okresie kursowania ZLT dość dużym wahaniom (rys. 4), a czynnikami mającymi na to wpływ były: pogoda i ogólna frekwencja, liczba osób z biletami miejskimi oraz pojawienie się wśród pasażerów grup zorganizowanych o różnej wielkości.

\section{WYKORZYSTANIE OFERTY W 2019 R. W ZALEŻNOŚCI OD PRZEWOŹNIKA}

Wysokość frekwencji, struktura pasażerów, a także różne sposoby zakupu biletów na przejazd Zabytkową Linią Tramwajową w zależności od przewoźnika są odzwierciedleniem różnego charakteru poszczególnych tras. Jak wspomniano, KSTM obsługiwał trasy A i B (rys. 1), łączące Stare Miasto z Halą Stulecia i sąsiadującym z nią kompleksem turystyczno-rekreacyjnym (park Szczytnicki, Ogród Japoński, zoo, Centrum Poznawcze, w bliskim sąsiedztwie Stadion Olimpijski i dzielnica modelowych budynków w stylu modernistycznym, tzw. WuWA, ostatnio poddawana rewitalizacji). Tramwaje zatrzymywały się na wszystkich mijanych przystankach, a komentarz przewodnika oferowany był tylko na jednej, ostatniej parze kursów (o 16.00 z opery do Hali Stulecia i o 17.00 z powrotem). KSTM organizował sześć kursów dziennie (trzy na trasie A do Hali Stulecia i trzy na trasie B do opery), co przez 30 dni (soboty, niedziele i święta) dało 180 kursów (w tym 60 z przewodnikiem). Natomiast TMW obsługiwało tramwaje jeżdżące bez żadnego przystanku trasą $C$ (rys. 1), która kluczyła po centrum miasta. Do pojazdu można było wsiąść wyłącznie przy operze. W zamian otrzymywało się prawie godzinny przejazd, zawsze w towarzystwie przewodnika opowiadającego o mijanych zabytkach i wydarzeniach historycznych rozgrywających się w pobliżu trasy tramwaju. Na trasie C odbywało się pięć przejazdów dziennie, co przez cały sezon dało 140 kursów (tramwaje obsługiwane przez TMW jeździły w weekendy, ale w święta nie, dlatego łącznie kursowały przez $28 \mathrm{dni}$ ).

Z kursów zapewnianych przez KSTM przez cały sezon skorzystało 3048 pasażerów, z czego 61,75\% miało bilet miejski, a 38,25\% zakupiło bilety w tramwaju. Z kolei z oferty TMW skorzystało 1445 pasażerów, w tym tylko 21,52\% wykorzystało posiadane bilety miejskie, 78,48\% zaś nabyło bilety sprzedawane wyłącznie na przejazd Zabytkową Linią Tramwajową (rys. 5). W przypadku tras A i B zwraca uwagę ponad dwukrotnie większa frekwencja $(2,11)$, przy czym wykonywano na nich tylko jeden kurs więcej niż na trasie C, i prawie trzykrotnie wyższy udział pasażerów korzystających z biletów miejskich $(2,87)$. Wynika to na pewno z lepszej dostępności tras obsługiwanych przez KSTM, ponieważ do tramwajów można było wsiąść w różnych miejscach miasta, przesiadając się z regularnych linii komunikacji miejskiej. W większym stopniu z omawianej oferty mogli korzystać wrocławianie, zwłaszcza że wagony dowoziły pasażerów na tereny, które są popularnymi miejscami weekendowego wypoczynku. Ta grupa z kolei znacznie powszechniej korzysta z biletów miejskich niż turyści. Przejazdy trasami A i B dla osób spoza Wrocławia były jednak również atrakcyjne, ponieważ nie tylko pozwalały na dotarcie do zabytku wpisanego na listę światowego dziedzictwa kulturalnego UNESCO (Hala Stulecia), ale umożliwiały także zobaczenie innych zabytków i atrakcji - przejażdżkę starym tramwajem można było rozpocząć lub zakończyć w ich bezpośrednim sąsiedztwie. Z kolei trasa C była bardziej hermetyczna, odpowiednia dla osób 
(przede wszystkim turystów), które chciały wygodnie i szybko dotrzeć do najważniejszych miejsc Starego Miasta i rewitalizowanego ostatnio Nadodrza. Gorsza dostępność skutkowała mniejszą frekwencja, a wśród pasażerów dominowały osoby spoza Wrocławia, które niekoniecznie posiadały bilety miejskie.

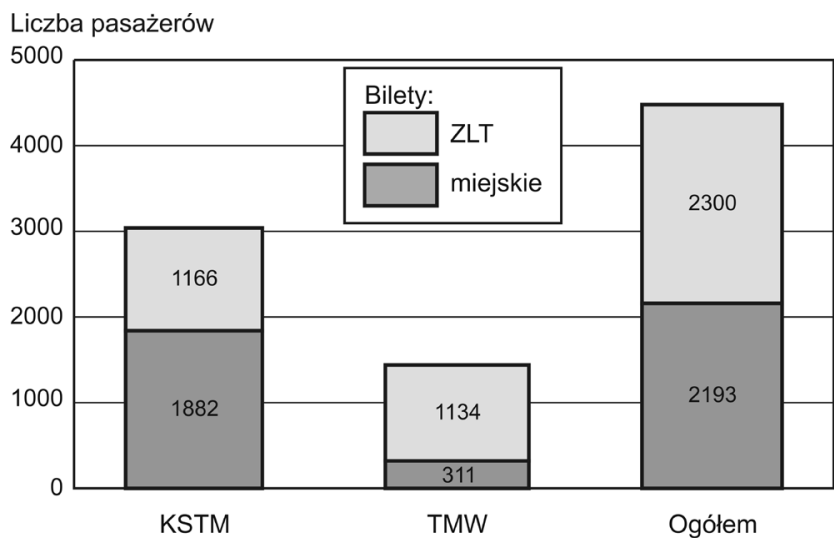

Rysunek 5. Struktura pasażerów Zabytkowej Linii Tramwajowej w 2019 r. według przewoźników i sposobu zakupu biletu Źródło: opracowanie własne

Potwierdzeniem powyższych obserwacji są dane dla poszczególnych dni funkcjonowania Zabytkowej Linii Tramwajowej (rys. 6). Prawie każdego dnia KSTM przewiózł więcej pasażerów niż TMW. Wyjątkami były 22 czerwca (odpowiednio 58 i 82 pasażerów) i 14 lipca (78 względem 99 osób). Największa względna przewaga KSTM nad TMW (iloraz liczby osób przewiezionych przez KSTM względem TMW) w zakresie frekwencji wyniosła 15,8 (30 czerwca), 4,94 (29 czerwca) i 4,21 (15 czerwca), w wartościach bezwzględnych zaś największa różnica to 119 osób (8 września; oczywiście pomija się tu 20 czerwca i 15 sierpnia, kiedy TMW nie kursowało). W każdym dniu funkcjonowania Zabytkowej Linii Tramwajowej udział pasażerów korzystających z biletów miejskich był wyższy (czasem nawet wyraźnie) na trasach obsługiwanych przez KSTM (rys. 6). $\mathrm{W}$ tym przypadku tylko czterokrotnie wynosił on poniżej 50\%, najmniej (36,89\%) - 16 czerwca, czyli w drugim dniu kursowania linii. Największą wartość (90,35\%) odsetek ten uzyskał 10 sierpnia, najczęściej zawierał się zaś $\mathrm{w}$ przedziale $50-70 \%$, przy czym w czerwcu i lipcu można zauważyć większe wahania wartości niż w sierpniu i we wrześniu. Z kolei w przypadku trasy $C$ ani razu nie osiągnięto wartości powyżej $50 \%$, tylko raz przekroczono $40 \%$ (i to nieznacznie $-42,22 \%$ ), najczęściej zaś udział ten wynosił 10-30\%. Największą różnicę między odsetkami osób korzystających z biletów miejskich na trasach KSTM i TMW odnotowano 10 sierpnia, kiedy wyniosła ona 71,6 punktów procentowych (90,35\% względem $18,75 \%$ ).

Ponieważ na trasach A i B wyraźnie wyższy był udział pasażerów z biletami miejskimi, to pod wzglę-

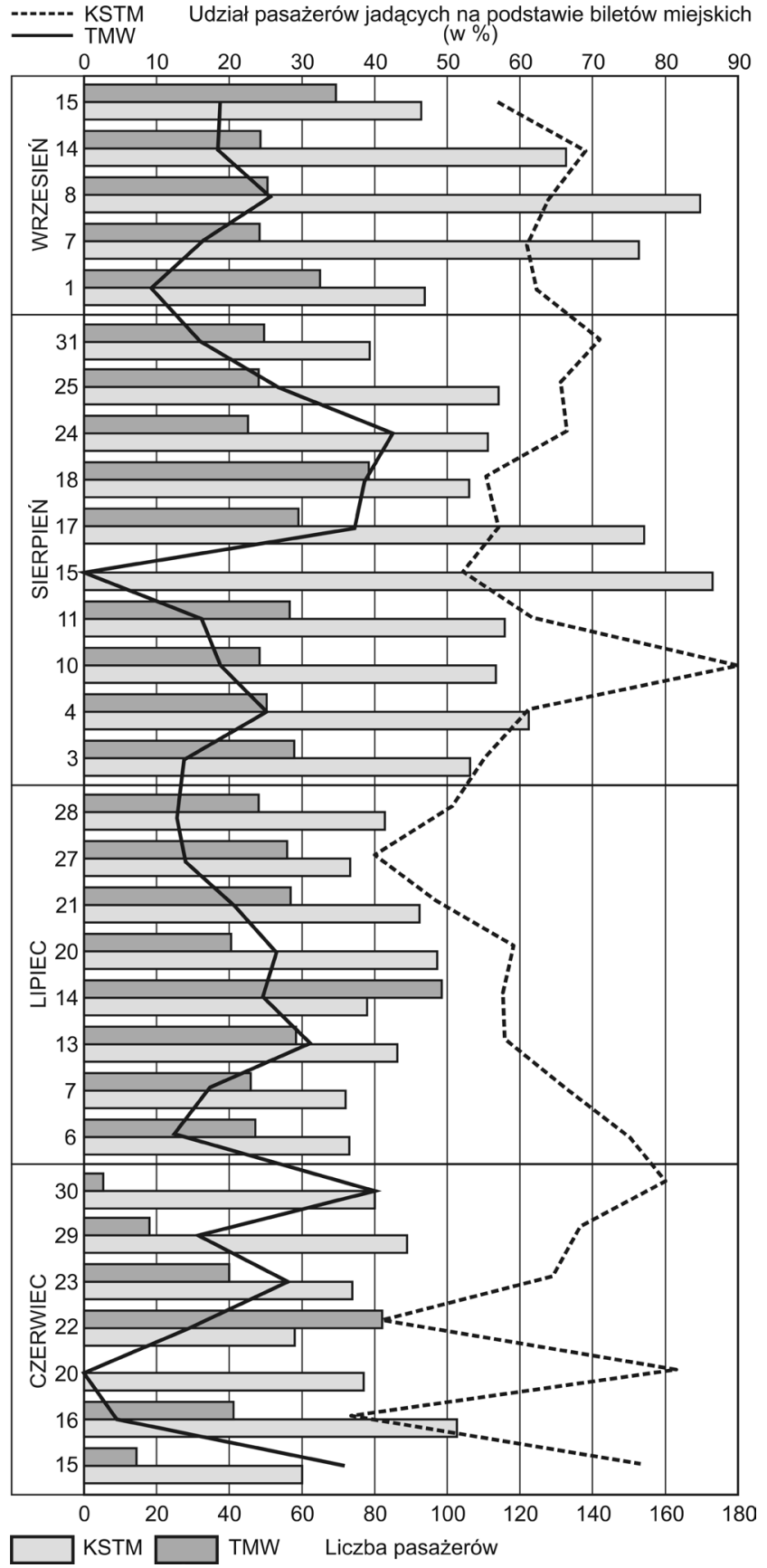

Rysunek 6. Liczba pasażerów Zabytkowej Linii Tramwajowej w 2019 r. według przewoźników i typów biletów Źródło: opracowanie własne

dem liczby sprzedanych biletów uprawniających wyłącznie do przejazdu Zabytkową Linią Tramwajową przewaga KSTM nad TMW była niewielka. Pierwsze stowarzyszenie rozdysponowało 1166 biletów (944 normalne i 222 ulgowe), drugie zaś - 1134 bilety (597 normalnych i 537 ulgowych; rys. 3). Zwraca uwagę wyraźnie większy udział biletów ulgowych na trasie C (47,35\% względem $19,04 \%$ na trasach A i B), trudny do jednoznacznego wyjaśnienia. Być może pojawiało się tam więcej osób, którym przysługiwała ulga (głównie studenci, emeryci i renciści), ewentualnie motorniczowie, którzy 
na trasie C zajmowali się sprzedażą biletów, niewłaściwie stosowali obowiązującą taryfę. Biorąc pod uwagę relatywnie wąską grupę osób, dla których w 2019 r. przewidziano bilety ulgowe (po przyznaniu bezpłatnych przejazdów dzieciom i młodzieży uczącej się do 21. roku życia oraz osobom, które ukończyły 68 lat), tak wysoki odsetek budzi wątpliwości. Pomijając dni, kiedy kursy wykonywał tylko KSTM, podczas 13 z 28 dni większą liczbę biletów sprzedała właśnie ta organizacja, zaś w czasie 15 dni - TMW (rys. 7).

Powyższe zależności przekładają się na przychody ze sprzedaży biletów (rys. 3 i 8). Pomimo niewielkiej

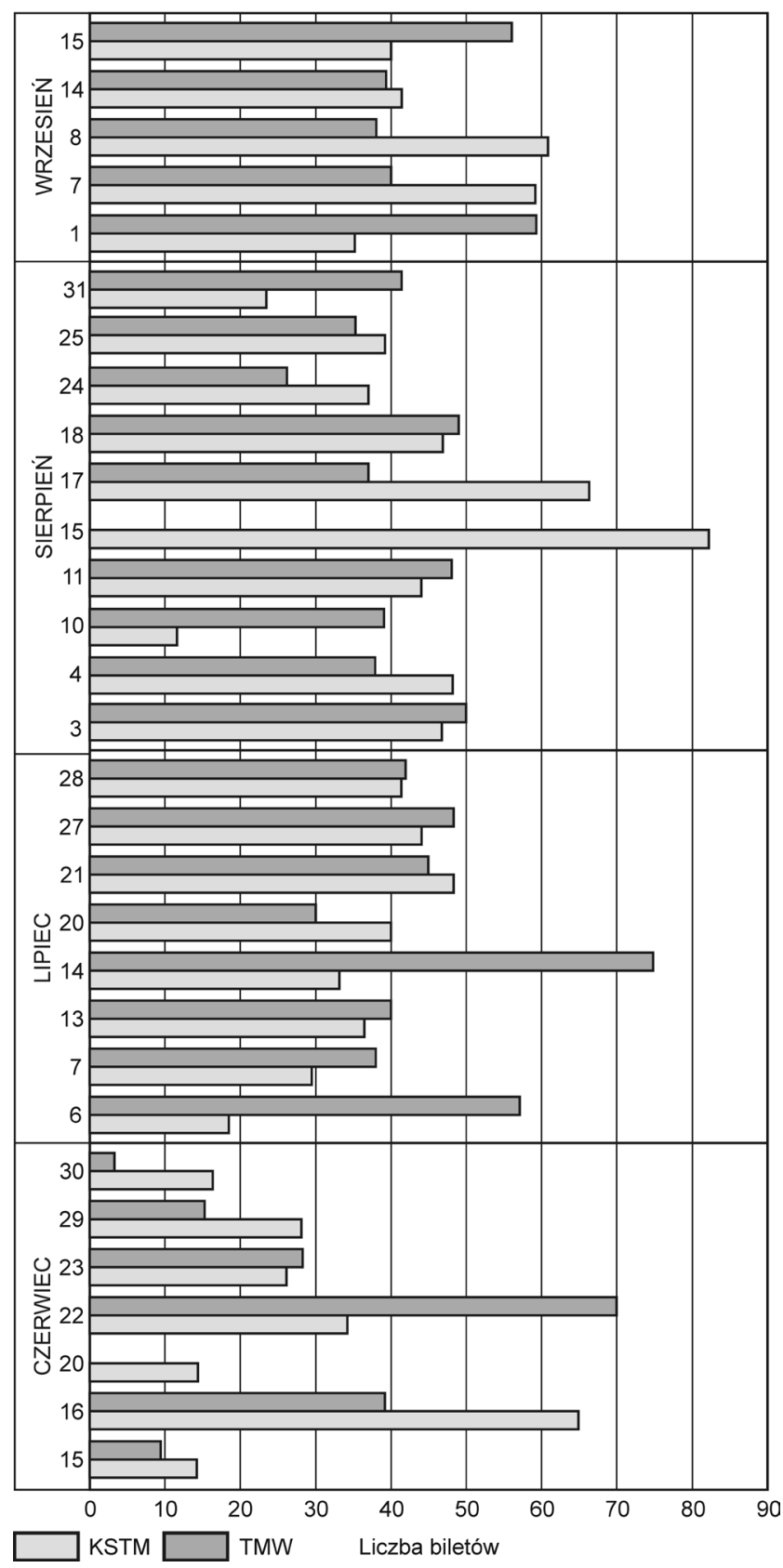

Rysunek 7. Liczba sprzedanych biletów Zabytkowej Linii Tramwajowej w 2019 r.

(łącznie normalne i ulgowe) według przewoźników Źródło: opracowanie własne przewagi KSTM pod względem ogólnej liczby rozdysponowanych biletów organizacja ta uzyskała wyraźnie większe przychody (3587,00 zł względem 2942,70 zł w przypadku TMW), na co wpływ miał znacząco wyższy odsetek biletów normalnych (rys. 3). Udział biletów ulgowych w przychodach KSTM wyniósł tylko 10,52\%, w przypadku TMW zaś-31,02\%. W konsekwencji, biorąc pod uwage poszczególne dni, KSTM miał przychody wyższe od TMW znacznie częściej niż w przypadku analizy danych o liczbie sprzedanych biletów. W ciagu branych pod uwagę 28 dni (pomijając święta) miało to miejsce aż 20 razy (rys. 8). Uwage przykuwają trzy dni, kiedy zaznaczyła się jednak bardzo wyraźna przewaga TMW nad KSTM. Przypadły one na początek sezonu (22 czerwca oraz 6 i 14 lipca) i mogły wynikać z przejazdu trasą C grupy zorganizowanej. Przykładowo 14 lipca TMW sprzedało aż 38 biletów ulgowych, co jest drugą najwyższą liczbą w sezonie (maksymalna wartość - 43 bilety ulgowe - została odnotowana 1 września), z czego aż 15 w czasie jednego kursu (co znów jest drugą najwyższą wartościa, podczas gdy maksymalną liczbę biletów - 18 - sprzedano także 1 września). KSTM najwyższy przychód uzyskał 15 sierpnia, kiedy TMW nie wystawiło tramwaju i potencjalni pasażerowie mieli do dyspozycji mniej kursów, a także 17 sierpnia i 8 września (identyczne wartości) oraz 16 czerwca. Wysokie przychody KSTM w przedostatni weekend kursowania Zabytkowej Linii Tramwajowej (jak również duża frekwencja i liczba sprzedanych biletów - por. rys. 6, 7 i 8) mogą mieć związek z odbywającą się 7 września dużą imprezą (Dzień Otwarty Zajezdni Popowice), podczas której organizacja ta udostępnia dla zwiedzających zabytkową zajezdnię tramwajową wraz ze zgromadzonym w niej historycznym taborem komunikacji miejskiej. W wydarzeniu tym bierze udział kilka tysięcy odwiedzających. Wielu $\mathrm{z}$ nich to miłośnicy transportu zbiorowego z różnych miast, korzystający przy okazji z oferty regularnej linii turystycznej (tym bardziej że w dniu imprezy specjalna linia, także obsługiwana zabytkowymi tramwajami, łączy Zajezdnię Popowice z opera, gdzie jest skomunikowana z odjazdami na trasie A Zabytkowej Linii Tramwajowej). Ponieważ w łącznych przychodach ze sprzedaży TMW miało wyższy udział biletów ulgowych niż KSTM, ta przewaga jest typowa również wtedy, gdy analizuje się zyski w poszczególnych dniach (rys. 8). KSTM tylko dwa razy w całym sezonie (pomijając dni, kiedy tramwaje obsługiwane przez TMW nie kursowały) mógł pochwalić się wyższym udziałem biletów ulgowych, a raz (w pierwszym dniu kursowania) osiągnął wartość zbliżoną. Poza tym wyższe udziały - z reguły dwu- lub trzykrotnie - miało TMW.

Wielu informacji o funkcjonowaniu Zabytkowej Linii Tramwajowej w 2019 r. dostarczają dane pokazujące sumaryczną frekwencję na poszczególnych kursach w całym sezonie, czyli od 15 czerwca do 15 września. 


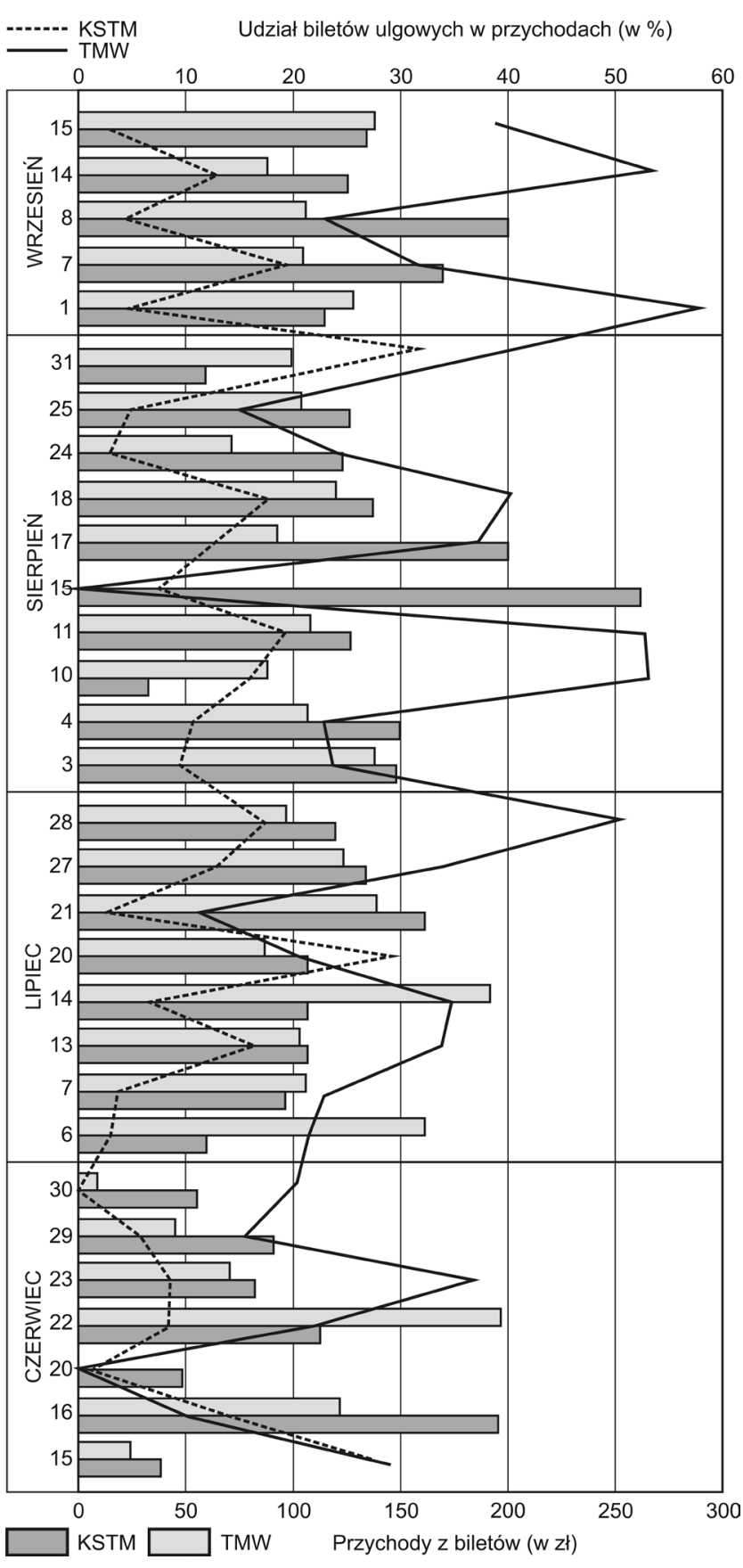

Rysunek 8. Przychody z biletów Zabytkowej Linii Tramwajowej w 2019 r. według przewoźników i typów biletów Zródło: opracowanie własne

W przypadku tras obsługiwanych przez KSTM (tab. 2) wyraźnie większą popularnością cieszyła się trasa A (przejazdy o 12.00, 14.00 i 16.00) niż B (kursy o 13.00, 15.00 i 17.00). Z pierwszej opcji skorzystało 1788 osób, z drugiej zaś - 1260. Można wnioskować, że linia uznawana jest za atrakcyjny sposób na dotarcie do terenów rekreacyjnych we wschodniej części miasta, ale powrót odbywa się już zwykłymi środkami komunikacji miejskiej. Być może wynika to z relatywnie krótkiego czasu kursowania w ciągu doby, ponadto godzina odjazdu ostatniego tramwaju z Hali Stulecia $\left(17.00^{10}\right)$ jest po prostu zbyt wczesna, biorąc pod uwagę długość dnia. Dodatkowo brak biletów powrotnych nie mobilizował do korzystania z obu tras łącznie. W przypadku trasy A wyższą (i zbliżoną) popularnością cieszyły się pierwszy i ostatni kurs, na trasie B zaś - kolejno trzeci i drugi. Można z tego wnioskować, że linia być może powinna kursować dłużej. Wysoka frekwencja osób jadących pierwszym kursem z opery może wskazywać, że kurs wcześniejszy także byłby chętnie wybierany przez podróżnych (np. o godz. $\left.10.00^{11}\right)$. Podobnie duża liczba osób zainteresowanych ostatnim kursem z Hali Stulecia sugeruje, że byłoby zapotrzebowanie na późniejszy kurs na trasie B. Dane pozwalają też przypuszczać, że pasażerowie spędzają w okolicach Hali Stulecia dłuższy czas i niekoniecznie wracają najbliższym kursem. Biorąc z kolei pod uwagę pary kursów, największą popularnością cieszyła się ostatnia para (1079 osób; z pierwszej pary kursów skorzystało 992 podróżnych, a z drugiej - 977), która wyróżniała się na tle innych obsługą przewodnicką. Średnia liczba pasażerów podczas jednego kursu wahała się od 12,40 do 20,67, pozostając w bezpośrednim związku z frekwencją. Wartości te nie są zbyt wysokie, zwłaszcza jeśli weźmie się pod uwagę, że na trasach A i B najczęściej pojawiał się tramwaj Konstal 102Na z 32 miejscami siedzącymi, choć trzeba też pamiętać, że kilkukrotnie jeździł wagon Konstal N z 1949 r., w którym jest tylko 12 siedzeń (Lubka, Stiasny, 2010; Żurawicz, 2013). Należy jednocześnie dodać, że 12 razy z jednego kursu skorzystały więcej niż 32 osoby, co oznacza, że wszystkie miejsca siedzące były zajęte. Maksymalnie podczas jednego kursu przewieziono 65 pasażerów. Trudno z kolei zauważyć jakieś szczególne zależności w odniesieniu do struktury wykupionych biletów. Udział pasażerów jadących na podstawie biletów miejskich wynosił niezależnie od kursu ok. $60 \%$, z nieco wyższą wartością $(67,74 \%)$ w czasie kursu o 13.00. Pasażerowie korzystający z przejazdu ulgowego stanowili od 5,97\% (godz. 15.00) do 9,81\% (godz. 17.00) ogółu pasażerów na poszczególnych kursach w skali całego sezonu, z kolei udział biletów ulgowych w łącznej liczbie sprzedanych biletów ZLT wynosił od 15,6\% (godz. 14.00) do 24,47\% (godz. 17.00).

W przypadku trasy C, obsługiwanej przez TMW (tab. 3), największą frekwencję odnotowano podczas pierwszego kursu, a następnie trzeciego, najmniejszą zaś - na drugim. Trudno ten fakt wyjaśnić, ale być może wpływ na to miała pora obiadowa. Średnia liczba pasażerów jadących jednym kursem wyniosła od 8,79 do 12,68 , co także wydaje się wynikiem niskim, ale trzeba pamiętać, że w soboty na analizowanej trasie $\mathrm{z}$ reguły kursował wagon Linke-Hofmann Standard z 1929 r. z 16 miejscami siedzącymi, natomiast $w$ niedziele był to wóz Konstal 102N z 1969 r. z 32 siedzeniami dla pasażerów. Udział podróżnych, którzy kupili bilety miejskie, znacznie niższy niż w przypadku przejazdów pojazdami obsługiwanymi przez KSTM, wykazywał się nieco 
Tabela 2. Sumaryczna frekwencja podczas poszczególnych kursów na trasach A i B Zabytkowej Linii Tramwajowej, obsługiwanych przez KSTM w całym sezonie w 2019 r. (15 czerwca-15 września)

\begin{tabular}{|l|c|c|c|c|c|c|}
\hline \multirow{2}{*}{ Kurs } & \multirow{2}{*}{$\begin{array}{c}\text { Liczba } \\
\text { pasażerów } \\
\text { łącznie }\end{array}$} & \multicolumn{3}{|c|}{ Liczba pasażerów korzystających } & \multirow{2}{*}{$\begin{array}{c}\text { Średnia liczba pasażerów } \\
\text { jadących jednym kursem }\end{array}$} & $\begin{array}{c}\text { Udział pasażerów } \\
\text { korzystających } \\
\text { z biletów }\end{array}$ \\
\cline { 3 - 6 } & ZLT ulgowych & ZLT normalnych & miejskich & \\
\hline 12.00 & 620 & 47 & 199 & 374 & 20,67 & 60,32 \\
\hline 13.00 & 372 & 25 & 95 & 252 & 12,40 & 67,74 \\
\hline 14.00 & 558 & 34 & 184 & 340 & 18,60 & 60,93 \\
\hline 15.00 & 419 & 25 & 129 & 265 & 13,97 & 63,25 \\
\hline 16.00 & 610 & 45 & 195 & 370 & 20,33 & 60,66 \\
\hline 17.00 & 469 & 46 & 142 & 281 & 15,63 & 59,91 \\
\hline Suma & 3048 & 222 & 944 & 1882 & 16,93 & 61,75 \\
\hline
\end{tabular}

Źródło: opracowanie własne.

Tabela 3. Sumaryczna frekwencja podczas poszczególnych kursów na trasie C Zabytkowej Linii Tramwajowej w całym sezonie 2019 r. (15 czerwca-15 września)

\begin{tabular}{|l|c|c|c|c|c|c|}
\hline \multirow{2}{*}{ Kurs } & \multirow{2}{*}{$\begin{array}{c}\text { Liczba } \\
\text { pasażerów } \\
\text { łącznie }\end{array}$} & \multicolumn{3}{|c|}{ Liczba pasażerów korzystających } & \multirow{2}{*}{$\begin{array}{c}\text { Średnia liczba pasażerów } \\
\text { j biletów }\end{array}$} & $\begin{array}{c}\text { Udział pasażerów } \\
\text { korzystających } \\
\text { z biletów miejskich }\end{array}$ \\
\cline { 3 - 6 } & ZLT ulgowych & ZLT normalnych & miejskich & & 19,15 \\
\hline 13.30 & 355 & 140 & 147 & 68 & 12,68 & 20,33 \\
\hline 14.30 & 246 & 92 & 104 & 50 & 8,79 & 23,51 \\
\hline 15.30 & 302 & 143 & 88 & 71 & 10,79 & 17,44 \\
\hline 16.30 & 258 & 88 & 125 & 45 & 9,21 & 27,11 \\
\hline 17.30 & 284 & 74 & 133 & 77 & 10,14 & 21,52 \\
\hline Suma & 1445 & 537 & 597 & 311 & 10,32 & \\
\hline
\end{tabular}

Źródło: opracowanie własne.

większą zmiennością - od 17,44\% do 27,11\%. Na trasach A i B na każdym z kursów w skali całego sezonu najwięcej pasażerów korzystało z biletów miejskich, następnie z uprawniających do przejazdów analizowaną linią biletów normalnych i dopiero ulgowych, natomiast w przypadku TMW te relacje są bardzo zmienne. $Z$ reguły najmniej podróżnych korzystało z biletów miejskich, ale wyjątkiem jest kurs o godz. 17.30 - wówczas takich osób było więcej niż pasażerów, którzy kupili ulgowe bilety Zabytkowej Linii Tramwajowej. Z kolei gdy mowa o proporcjach między sprzedanymi biletami normalnymi i ulgowymi, to pasażerowie częściej nabywali te pierwsze. Niemniej jednak podczas kursu o godz. 15.30 podróżni chętniej kupowali bilety ulgowe, w czasie przejazdu o godz. 13.30 zaś wartości były bardzo zbliżone.

\section{PORÓWNANIE WYKORZYSTANIA OFERTY W 2018 I 2019 R.}

Porównanie przeprowadzono, opierając się na danych pochodzących od obu stowarzyszeń obsługujących Zabytkową Linię Tramwajową w 2018 i 2019 r., z wyjątkiem
MPK, które w 2018 r. realizowało kursy na konkurencyjnej linii, a w 2019 r. znacznie zwiększyło działalność przewozową analizowanej linii, wydłużając okres jej funkcjonowania i zwiększając częstotliwość przejazdów. Danych uwzględniających kursy organizowane przez MPK nie należy więc porównywać, gdyż dotyczą różnych ofert i okresów. Analiza dla obu lat (tab. 4) objęła czas od połowy czerwca (16 czerwca $2018 \mathrm{r}$. i 15 czerwca 2019 r.) do pierwszej połowy września (9 września 2018 r. i 15 września 2019 r.). W 2019 r. zrealizowano o 34 kursy więcej niż w 2018 r., ponieważ sezon był o jeden weekend dłuższy, ponadto tramwaje obsługiwane przez KSTM kursowały także w święta. Konsekwencją była też wyższa liczba przejazdów z przewodnikiem. Zarówno w 2018 r., jak i w 2019 r. KSTM wykonywał więcej wozokilometrów, ale TMW organizowało więcej kursów z komentarzem przewodnika. W 2019 r. wyraźnie zwiększyła się liczba pasażerów - na trasach obsługiwanych przez KSTM wzrosła o 34,75\% względem 2018 r., na linii, na której za organizowanie przejazdów odpowiadało TMW - aż o 65,33\%, łącznie zaś - o 43,27\%. Mniejszy wzrost w przypadku tras A i B można tłumaczyć tym, że były one obsługiwane także przez MPK, więc pasażerowie mieli do 
Tabela 4. Porównanie wykorzystania oferty Zabytkowej Linii Tramwajowej w 2018 i 2019 r.

\begin{tabular}{|l|c|c|c|c|c|c|}
\hline \multirow{2}{*}{ Cecha } & \multicolumn{3}{|c|}{ Sezon 2018 } & \multicolumn{3}{c|}{ Sezon 2019 } \\
\cline { 2 - 7 } & Łącznie & $\begin{array}{c}\text { Trasy A i B } \\
\text { (KSTM) }\end{array}$ & $\begin{array}{c}\text { Trasy C i D } \\
\text { (TMW) }\end{array}$ & Łącznie & $\begin{array}{c}\text { Trasy A i B } \\
\text { (KSTM) }\end{array}$ & $\begin{array}{c}\text { Trasa C } \\
\text { (TMW) }\end{array}$ \\
\hline Liczba kursów ogółem & 286 & 156 & 130 & 320 & 180 & 140 \\
\hline Liczba kursów z przewodnikiem & 156 & 52 & 104 & 200 & 60 & 140 \\
\hline Liczba pasażerów ogółem & 3136 & 2262 & 874 & 4493 & 3048 & 1445 \\
\hline $\begin{array}{l}\text { Udział pasażerów korzystających } \\
\text { z biletów miejskich }\end{array}$ & 0,00 & 0,00 & 0,00 & 48,81 & 61,75 & 21,52 \\
\hline $\begin{array}{l}\text { Średnia liczba pasażerów } \\
\text { na jeden kurs }\end{array}$ & 10,97 & 14,50 & 6,72 & 14,04 & 16,93 & 10,32 \\
\hline $\begin{array}{l}\text { Łączna liczba } \\
\text { sprzedanych biletów }\end{array}$ & 2017,00 & 1071 & 946 & 2300 & 1166 & 1134 \\
\hline $\begin{array}{l}\text { Udział biletów ulgowych w ogóle } \\
\text { sprzedanych biletów }\end{array}$ & 51,61 & 31,65 & 74,21 & 33,00 & 19,04 & 47,35 \\
\hline Przychody (zł) & 15634,00 & 10370,00 & 5264,00 & 6529,70 & 3587,00 & 2942,70 \\
\hline $\begin{array}{l}\text { Udział biletów ulgowych } \\
\text { w przychodach }\end{array}$ & 28,49 & 15,87 & 53,34 & 19,76 & 10,52 & 31,02 \\
\hline
\end{tabular}

Uwagi: Liczba pasażerów, którzy korzystali z ZLT w 2018 r., określona została szacunkowo na podstawie sprzedanych biletów z założeniem, że z biletu rodzinnego korzystały cztery osoby (w praktyce mogło to być od trzech do pięciu osób).

Źródło: opracowanie własne.

wyboru większą liczbę kursów (siedem par zamiast trzech w 2018 r.). Pomimo tego KSTM także odnotował wyższą frekwencję na zapewnianych przez siebie kursach tramwajów. Dużo większy wzrost zainteresowania trasą C wskazuje jednak, że oferta przewodnika jest pożądana i pasażerowie cenią sobie spokojny (bez przystanków pośrednich i wymiany pasażerskiej) przejazd po centrum miasta.

Ważniejsze jest jednak porównanie średniej liczby osób przypadających na jeden kurs, ponieważ wartości te niwelują wpływ różnego okresu kursowania w latach uwzględnionych $\mathrm{w}$ analizie. W takim ujęciu w $2019 \mathrm{r}$. odnotowano, że pasażerów było łącznie o 27,99\% więcej, na co składa się wzrost o $16,6 \%$ na trasach obsługiwanych przez KSTM i o 53,57\% podczas kursów organizowanych przez TMW. Widać więc wyraźnie, że modyfikacje wprowadzone w 2019 r. przyczyniły się do zwiększenia popularności, wynikającego zapewne głównie ze zmiany taryfy i uwzględnienia biletów miejskich. Co jednak ciekawe, pomimo tego, że prawie połowa pasażerów $(48,81 \%)$ korzystała z biletów miejskich, w 2019 r. wzrosła też liczba sprzedanych biletów - o 14,03\% ogółem, o 8,87\% na trasach obsługiwanych przez KSTM i 19,87\% na kursach organizowanych przez TMW. Trzeba jednak pamiętać, że wpływ na to miała przede wszystkim zmiana taryfy, gdyż w 2019 r. oferowano wyłącznie bilety jednorazowe, rok wcześniej zaś były to też bilety powrotne i rodzinne, więc chociaż formalnie sprzedawano jeden bilet, to pojedynczy pasażer lub grupa osób odbywały nawet dwa przejazdy. Zmiana sposobów płatności za przejazd odbiła się jednak negatywnie na przychodach, które w 2019 r. były o 58,23\% niższe niż w poprzednim roku (w przypadku KSTM stanowiły 34,59\% uzyskanych w 2018 r., zaś w odniesieniu do TMW -55,90\%). Trzeba jednak pamiętać, że Zabytkowa Linia Tramwajowa to specyficzne zadanie, które bez dotacji z Urzędu Miejskiego nie miałoby racji bytu. Nawet w 2018 r. zyski, które były wówczas dość wysokie, nie starczały na pokrycie podstawowych kosztów funkcjonowania linii (Kołodziejczyk, 2019). Określenie sposobu płatności za przejazd jest więc właściwie decyzją polityczną przy której podejmowaniu należy uwzględniać dostępność linii dla ogółu turystów i wrocławian oraz poziom, na jakim władze są skłonne ją dotować. Zmiana taryfy miejskiej, która zapewniła bezpłatne przejazdy dzieciom i młodzieży uczącej się do ukończenia 21. roku życia, spowodowała spadek udziału biletów ulgowych w liczbie wszystkich sprzedanych biletów i w przychodach. W danych z 2018 i z 2019 r. uwagę zwraca jednak wyraźnie większe znaczenie tych biletów na trasach obsługiwanych przez TMW, zarówno gdy mowa o liczbie sprzedanych biletów (różnica ponad dwukrotna), jak i o ich udziale w przychodach (ponad trzykrotnie wyższym).

Podobnie jak w 2019 r., także w poprzednim roku zauważalny był wzrost frekwencji na linii w miare upływu czasu jej funkcjonowania, choć nie jest to wyraźna zmiana. Maksymalne wartości odnotowano raczej w lipcu i sierpniu, we wrześniu zaś nastąpił spadek zainteresowania. W odniesieniu do $2018 \mathrm{r}$. zgromadzono tylko dane o sprzedaży biletów, dlatego o frekwencji można wnioskować wyłącznie pośrednio, uznając, że jeden bilet powrotny powinien być liczony jako dwie 
podróże, i zakładając, że z biletów rodzinnych korzystały cztery osoby (w praktyce mogło być od trzech do pięciu - dwoje dorosłych i do trójki dzieci). Liczba pasażerów ma więc charakter szacunkowy. Ponadto autor artykułu dysponuje szczegółowymi danymi dziennymi tylko dla tras obsługiwanych przez KSTM, $\mathrm{w}$ przypadku TMW zaś posiada tylko informacje zbiorcze dla trzech okresów rozliczeniowych. Analizując frekwencję na trasach A i B, można zauważyć jej wzrost w lipcu względem czerwca (rys. 9), i to pomimo uruchomienia przez MPK na zbliżonej trasie w pewnym sensie konkurencyjnej linii. Potwierdzają to dane o przychodach (rys. 10). Tendencję tę nieco zaburza pierwszy weekend kursowania (16-17 czerwca), kiedy na linii po raz pierwszy pojawił się niedawno wyremontowany tramwaj Konstal 102Na, zatem mógł zadziałać efekt

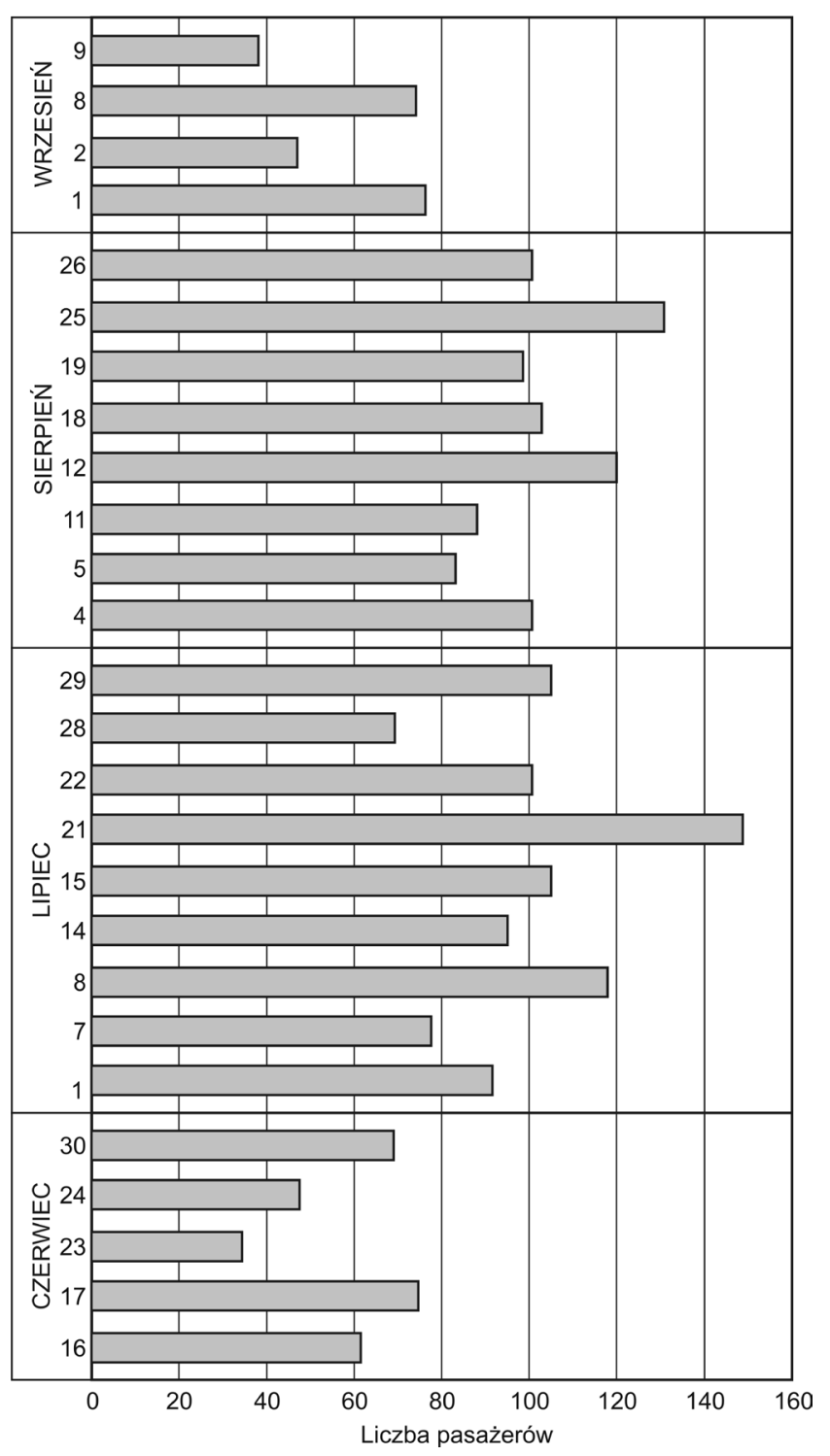

Rysunek 9. Szacunkowa frekwencja na trasach A i B Zabytkowej Linii Tramwajowej w $2018 \mathrm{r}$. określona na podstawie liczby sprzedanych biletów Źródło: opracowanie własne nowości, co skutkowało przyciągnięciem większej liczby pasażerów (byli to jednak w dużym stopniu miłośnicy komunikacji zbiorowej, ale raczej nie turyści). Średnia dzienna frekwencja na trasach obsługiwanych przez KSTM w czerwcu wyniosła 57,8 osoby, a przychód $271,00 \mathrm{zl}$, w lipcu odpowiednio 101,33 osoby i 454,40 zł, w sierpniu - 103,25 osoby i 456,00 zł, we wrześniu zaś - 58,75 osoby i 273,50 zł. Dane dla czerwca i września oraz lipca i sierpnia są więc bardzo zbliżone. Najwyższą dzienną frekwencję odnotowano 21 lipca i 25 sierpnia, a najmniejszą 23 czerwca i 9 września (rys. 9). Zbliżone są wyniki analizy przychodów, choć 25 sierpnia były one wyższe niż 21 lipca (rys. 10). Na wzrost frekwencji $\mathrm{w}$ miarę upływu czasu wskazuje m.in. porównanie liczby pasażerów i przychodów z biletów w drugi i przedostatni weekend kursowania linii (odpowiednio 83 i 123 osoby oraz 400,00 i 584,00 zł). Choć pogo-

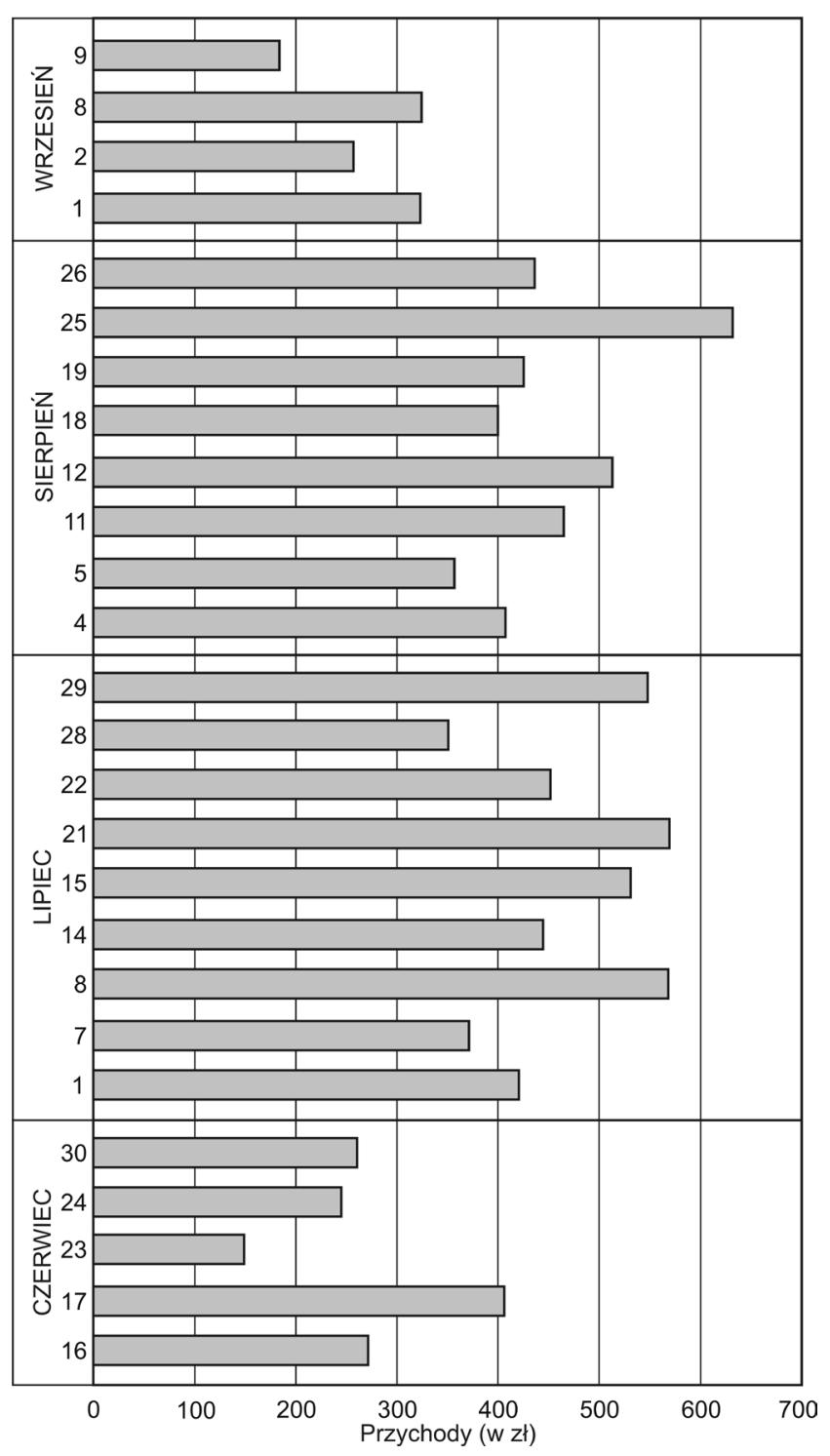

Rysunek 10. Przychody na trasach A i B Zabytkowej Linii Tramwajowej w 2018 r. Źródło: opracowanie własne 
da była porównywalna, to ostatni weekend wakacji cieszył się wyraźnie większym zainteresowaniem niż pierwszy. O coraz większej popularności linii w zależności od tego, jak długo ona funkcjonuje, świadczą dane zestawione dla wyżej wspomnianych okresów rozliczeniowych. W pierwszym (16 czerwca-1 lipca) TMW odnotowało średni dzienny przychód w wysokości 62,67 zł, w drugim (7-29 lipca) -270,50 zł, w trzecim zaś (4 sierpnia-9 września) - 227,00 zł. Dochody KSTM wynosiły natomiast odpowiednio 295,00 zł, 482,25 zł i 395,17 zł. Widać więc, że w obu przypadkach najwyższe przychody odnotowano w lipcu, a także zapewne w sierpniu, ale suma została zaniżona przez gorsze wyniki z września.

Analizując bardziej szczegółowe dane, należy zwrócić uwagę na zmianę popularności pary kursów z przewodnikiem na trasach A i B. W 2018 r. podczas tej pary przejazdów frekwencja była najmniejsza spośród trzech par kursów (w całym sezonie sprzedano na nią 308 biletów, na pierwszą parę zaś - 359 biletów, a na drugą - 404), co jest bardzo zaskakujące. Z kolei w 2019 r. ta para kursów cieszyła się największym zainteresowaniem (428 sprzedanych biletów, na pozostałe pary odpowiednio - 366 i 372; dane dotyczące frekwencji - por. tab. 2). O zmianie zdecydowała prawdopodobnie intensywniejsza promocja tych kursów zarówno przez KSTM, jak i przez Wrocławski Klub Przewodników, który zapewniał obsługę przewodnicką. Nie bez znaczenia była też zapewne swoista trwałość oferty, gdyż w obu sezonach kursy z przewodnikiem odbywały się o tych samych godzinach.

\section{WNIOSKI}

Zabytkowa Linia Tramwajowa we Wrocławiu jest właściwym sposobem wykorzystania - a w konsekwencji także utrzymania - dużej i bardzo różnorodnej kolekcji zabytkowych tramwajów, reprezentujących okres od 1893 r. do przedostatniej dekady XX w. (Bufe, 1992; Kołodziejczyk, 2011; Sielicki, 2012, 2013). Pomimo że omawiana linia stanowi produkt turystyczny o ugruntowanej pozycji, w ostatnich latach była poddawana licznym modyfikacjom, mającym na celu nie tylko zwiększenie frekwencji, która okazała się niezbyt wysoka względem ogólnej liczby dostępnych miejsc w tramwajach (Kołodziejczyk, 2019), ale także dostosowanie oferty do współczesnych potrzeb ruchu turystycznego. Zmiany wprowadzone w 2019 r., zwłaszcza wyraźne obniżenie cen biletów (zrównanie ich ze zwykłymi biletami jednorazowymi komunikacji miejskiej) i uznawanie wszystkich biletów miejskich, przyczyniły się do znaczącego wzrostu frekwencji - aż o ponad $40 \%$ względem 2018 r. Należy to więc uznać za dobre rozwiązanie, które zwiększa dostępność oferty. Wagony tramwajowe wpisane do rejestru lub ewidencji zabytków stanowią część dziedzictwa kulturowego i powinny być na odpowiednich zasadach udostępniane mieszkańcom i turystom. Choć na liniach turystycznych na świecie z reguły obowiązuje odrębna taryfa o wyższych cenach biletów (np. w Porto), to coraz częściej jest ona zrównywana z taryfą miejską (np. w Warszawie i wielu miastach czeskich, chociażby w Karlowych Warach) Nadaje to ofercie cechy paraturystyczne, co ma swoje wady, które zostaną omówione w dalszej części tekstu. Wydaje się jednak, że pozytywne aspekty przeważają nad negatywnymi.

Wskutek zmiany taryfy nastąpił oczywiście spadek przychodów, które w 2019 r. były o blisko 60\% niższe niż w roku poprzednim. Biorąc jednak pod uwagę fakt, że nawet w 2018 r. zyski z biletów nie wystarczyły na pokrycie podstawowych kosztów funkcjonowania linii (nie mówiąc o pracy przewodników, druku materiałów promocyjnych i utrzymaniu taboru, które jest niezbędne; por. Kołodziejczyk, 2019) i w każdym roku linia utrzymuje się głównie dzięki dotacji, wysokość tego dofinansowania jest tylko kwestią decyzji urzędniczej. Trzeba jednak zaznaczyć, że linia mogłaby przynosić większe dochody, jeśli umożliwiono by np. sprzedaż pamiątek, która obecnie - ze względu na zasady finansowania - nie jest dozwolona. Należy też zastanowić się nad zmianą godzin kursowania linii, by objąć nimi także poranki i wieczory, umożliwiając dojazd do terenów rekreacyjnych w okolicy Hali Stulecia i spędzenie tam całego dnia oraz powrót z organizowanych w tej części miasta wydarzeń (np. bardzo popularne pokazy fontanny multimedialnej). Oczywiście zwiększy to koszty, ale wyższa frekwencja może je zrównoważyć. Kluczowe jest także to, aby przyjąć stałą datę rozpoczęcia i zakończenia funkcjonowania Zabytkowej Linii Tramwajowej w danym roku, ponieważ w ostatnich latach terminy te były bardzo zmienne. W konsekwencji promocję w każdym roku trzeba zaczynać praktycznie od nowa, a turyści nie mają pewności, czy jeśli przyjadą np. w maju lub pod koniec września, będą mieli możliwość przejechania się zabytkowymi wagonami. Dobrym przykładem trwałości sezonowej oferty są cyklobusy (autobusy przystosowane do przewozu rowerów) w Republice Czeskiej (Kołodziejczyk, 2014b), których okres kursowania w głównych regionach turystycznych (np. Rudawy, Karkonosze czy Góry i Pogórze Orlickie) w każdym roku jest stały.

Problemem, który pojawił się w 2019 r. w związku z tym, że tramwaje na trasach A i B zatrzymywały się na wszystkich mijanych przystankach, było zapewnienie odpowiedniej jakości usługi przewodnickiej. Przy ciągłej wymianie pasażerów, sprzedaży i sprawdzaniu biletów przez konduktora oraz pojawianiu się w wagonie osób przypadkowych, które traktują zabytkowy tramwaj po prostu jako dogodny środek transportu do założonego celu, przewodnikowi trudno utrzymać 
właściwą narrację, a osobom zainteresowanym (głównie turystom) - słuchać. Problem utrzymałby się także w przypadku wprowadzenia audioprzewodników (dystrybucja urządzeń między zmieniającymi się pasażerami zapewne byłaby utrudniona), jak również przy odtwarzaniu wcześniej nagranych tekstów (mogłyby być one zagłuszane przez niezainteresowanych pasażerów; dodatkową trudność stanowiłoby zsynchronizowanie nagrań z prędkością przemieszczania się pojazdu). Wydaje się więc, że podczas kursów z przewodnikiem tramwaje powinny zatrzymywać się tylko w wybranych miejscach, np. przy głównych atrakcjach turystycznych, a niekoniecznie w węzłach przesiadkowych i na przystankach, w pobliżu których nie ma atrakcji turystycznych. W przypadku tras, na których przewodnik pojawia się tylko podczas wybranych kursów, można wprowadzić rozróżnienie w liczbie miejsc zatrzymywania się tramwajów. Lepszym rozwiązaniem wydaje się jednak podział oferty na trasę (trasy) z przewodnikiem, ale z bardzo ograniczoną liczbą przystanków oraz bez przewodnika, za to z zachowaniem wszystkich przystanków na trasie. Pierwsza opcja skierowana byłaby raczej do turystów, z drugiego wariantu mogliby zaś korzystać przede wszystkim mieszkańcy Wrocławia w celu dotarcia do miejsc weekendowego wypoczynku. Trzeba też podkreślić, że dla niektórych osób atrakcję stanowi sama przejażdżka zabytkowym tramwajem i niekoniecznie są one zainteresowane opowieścią o mijanych miejscach. Rozwiązaniem powyższych problemów mogłaby się stać aplikacja dla podróżnych, która pozwalałaby im na zapoznanie się $\mathrm{z}$ informacjami o tramwaju realizującym dany kurs, trasie przejazdu i mijanych atrakcjach. W ostatnim przypadku niezbędne byłoby powiązanie aplikacji z lokalizacją pojazdu. Ta ciekawa propozycja wymaga więc wyposażenia zabytkowych tramwajów w urządzenia do geolokalizacji oraz stworzenia odpowiedniego programu, co wiąże się z kosztami.

Zabytkowa Linia Tramwajowa w 2019 r. była oferta, która łączyła w sobie pewne elementy nadające jej cechy elitarności (zmiany wprowadzone w poprzednich latach, np. komentarz przewodnika lub bezpłatne ulotki historyczne) ze znacznym zwiększeniem dostępności, przez co wpisywała się w koncepcję egalitarności. Odnosząc się do analizy SWOT przeprowadzonej dla Zabytkowej Linii Tramwajowej w formie z 2018 r. (Kołodziejczyk, 2019), trzeba stwierdzić, że w 2019 r. utrzymały się wszystkie wymienione jej mocne strony, ale także większość słabych. Linia stała się jednak znacznie bardziej dostępna, gdyż usunięto główny mankament, czyli wysoką cenę biletów. Poza niemożnością zakupu pamiątek oraz brakiem kursów porannych czy wieczornych pozostałe słabe strony odnoszą się właściwie do wszystkich linii turystycznych i wynikają z charakterystyki komunikacji miejskiej, która odznacza się tym, że pasażer (turysta) musi dostosować się do tras i rozkładów jazdy. Jak dotąd nie wykorzystano jednak potencjalnych szans i utrzymały się wszystkie wskazane zagrożenia.

\section{PRZYPISY}

${ }^{1}$ Podstawową funkcją urządzeń turystycznych jest - zdaniem Rogalewskiego (1979) - obsługa uczestników ruchu turystycznego, natomiast urządzenia paraturystyczne zaspokajają potrzeby związane z innymi sferami życia społeczno-gospodarczego, a turyści korzystają z nich niejako przy okazji, jako jedna z wielu grup, wśród których dominują raczej mieszkańcy danego obszaru czy miejscowości (por. Kowalczyk, Derek, 2010). Podobnie infrastrukturę paraturystyczną (lub inaczej infrastrukturę ogólną) definiuje Płocka (2009), podkreślając, że służy ona różnym działom gospodarki narodowej, w tym obsłudze ruchu turystycznego. Jako przykład urządzeń paraturystycznych bardzo często wymienia się infrastrukturę komunikacyjną (Kowalczyk, Derek, 2010; Płocka, 2009), w którą Zabytkowa Linia Tramwajowa w pełni się wpisuje (zwłaszcza po zmianach wprowadzonych w 2019 r.). Czasem w tym kontekście stosowany jest termin „baza transportowa turystyki" (zob. np. Pawlikowska-Piechotka, 2009).

2 Przykładowo linie turystyczne w Porto docierają do muzeum komunikacji miejskiej, natomiast w Krakowie linia tramwajowa obsługiwana zabytkowym taborem zaczyna bieg przy Muzeum Inżynierii Miejskiej (por. Golonka, Pochwała, 2010).

3 Proste produkty składające się na produkt złożony na przykładzie linii kolejowych wykorzystywanych w turystyce przedstawił Kołodziejczyk (2014a). Wiele z wymienionych tam elementów może znaleźć zastosowanie także na miejskich liniach turystycznych obsługiwanych zabytkowym (ewentualnie stylizowanym) taborem.

${ }^{4}$ Egalitaryzm to teoria głosząca, że podstawą sprawiedliwego ustroju społecznego powinna być zasada równouprawnienia obywateli pod względem ekonomicznym, społecznym i politycznym (Kubisa-Ślipko, b.r.). W kontekście produktu turystycznego najważniejszy jest pierwszy aspekt i takie kształtowanie jego ceny, żeby był dostępny dla możliwie szerokiej grupy potencjalnych odbiorców.

${ }^{5} \mathrm{~W}$ trzech pierwszych latach funkcjonowania linia kursowała w piątki, soboty i niedziele, przy czym w piątki tylko w sezonie letnim. Od tego czasu pozostaje ofertą wyłącznie weekendową, co ma swoje uzasadnienie m.in. w dużym natężeniu ruchu tramwajowego na wybranych trasach w centrum miasta $\mathrm{w}$ dni robocze.

${ }^{6}$ Zabytkowa Linia Tramwajowa od początku realizowana jest przez organizacje pozarządowe jako zadanie publiczne. Co roku ogłaszany jest konkurs ofert na jej organizację i prowadzenie.

$7 \mathrm{~W}$ pierwszych latach funkcjonowania Zabytkowej Linii Tramwajowej zaplanowano po jednym przystanku na trasie do i z Hali Stulecia, ale później z nich zrezygnowano. Znajdowały się one w dużych węzłach przesiadkowych, co z jednej strony było korzystne pod względem frekwencji, ale z drugiej - czasami utrudniało ruch regularnych tramwajów przez dłuższy czas wymiany pasażerskiej (sprzedaż biletów) i postoju na przystanku.

8 Zaprezentowane w artykule dane z 2019 r. dotyczą tylko przejazdów organizowanych przez KSTM i TMW, czyli kursów w okresie od 15 czerwca do 15 września, kiedy oferta Zabytkowej Linii Tramwajowej była najbardziej rozbudowana.

${ }^{9}$ Analogiczna sytuacja miała miejsce 20 czerwca (Boże Ciało), ale wtedy średnia frekwencja podczas kursów realizowanych wyłącznie przez KSTM nie była aż tak wysoka (przy czym była to druga najwyższa wartość w czerwcu). 
${ }^{10}$ MPK realizowało jeszcze kurs z Hali Stulecia o godz. 17.45, ale był to przejazd do zajezdni, w związku z czym powrót do centrum miasta nie był możliwy.

${ }^{11}$ W 2019 r. pierwszy kurs na trasie A (o godz. 11.00) wykonywało MPK.

\section{BIBLIOGRAFIA}

Ashworth, G.J. (1992). Is there an urban tourism? Tourism Recreation Research, 17 (2), 3-8. DOI: https://doi.org/10.1080/ 02508281.1992.11014645

Bąk, S. (1999). Marketingowa koncepcja produktu turystycznego. W: K. Mazurek-Łopacińska (red.), Problemy zarzadzania sfera kultury i turystyki (s. 117-139). Warszawa-Wrocław: Wydawnictwo Akademii Ekonomicznej im. Oskara Langego we Wrocławiu.

Bufe, S. (red.) (1992). Strassenbahnen in Schlesien. Egglham: Bufe-Fachbuch-Verlag.

Cegielski, M., Mules, T. (2002). Aspects of residents' perceptions of the GMC 400 - Canberra's V8 supercar race. Current Issues in Tourism, 5 (1), 54-70. DOI: https://doi. org/10.1080/13683500208667908

Cohen, E. (1972). Toward a sociology of international tourism. Social Research, 1 (39), 164-189.

Coles, T.E. (2004). Tourism and retail transactions: Lessons from the Porsche experience. Journal of Vacation Marketing, 10 (4), 378-389. DOI: https://doi.org/10.1177/135676670401000408

Coles, T.E. (2008). International car manufactures, brandscapes and tourism: Engineering the experience economy. W: T.E. Coles, C.M. Hall (red.), International business and tourism: global issues, contemporary interactions (s. 238-255). Londyn: Routledge. DOI: https://doi.org/10.4324/9780203931035

Cudny, W. (2016). Manufaktura centre in Łódź, Poland: An example of a festival marketplace. Norwegian Journal of Geography - Norsk Geografisk Tidsskrift, 70 (5), 276-291. DOI: https://doi. org/10.1080/00291951.2016.1239654

Cudny, W. (2018). Car tourism. Cham: Springer. DOI: https://doi. org/10.1007/978-3-319-62084-8

Cudny, W., Horňák, M. (2016). The tourist function in a modern car factory Audi Forum Ingolstadt example. Bulletin of Geography. Socio-economic Series, 33, 23-38. DOI: https://doi. org/10.1515/bog-2016-0022

Cudny, W., Jolliffe, J. (2019). Car tourism - conceptualization and research advancement. Geografický časopis/Geographical Journal, 71 (4), 319-340. DOI: https://doi.org/10.31577/ geogrcas.2019.71.4.17

Dolles, H., Dibben, M.R., Hardy, A. (2018). Motorcycle racing and neo-tribes at the Isle of Man. W: A. Hardy, A. Bennett, B. Robards B. (red.), Neo-tribes (s. 119-134). Cham: Palgrave Macmillan. DOI: https://doi.org/10.1007/978-3-319-68207-5_8

Golonka, M., Pochwała, S. (2010). Rewaloryzacja i adaptacja zajezdni na cele muzealne w ramach projektu „Kwartał św. Wawrzyńca - budowa centrum kulturowego na krakowskim Kazimierzu". W: E. Wyka (red.), Biuletyn Muzeum Inżynierii Miejskiej w Krakowie (z. 3) (s. 58-70). Kraków: Muzeum Inżynierii Miejskiej w Krakowie.

Jędrysiak, T. (2011). Turystyka kulturowa w obiektach przemysłowych - zagadnienia ogólne. Turystyka Kulturowa, 6 (2011), 17-35.

Kaczmarek, J., Stasiak, A., Włodarczyk, B. (2010). Produkt turystyczny. Pomyst, organizacja, zarzadzanie. Warszawa: Polskie Wydawnictwo Ekonomiczne.

Kokoszkiewicz, M. (2019). Więcej zabytkowych tramwajów rusza w miasto. W tym roku aż trzy linie. Pobrane z: https://wroclaw. wyborcza.pl/wroclaw/7,35771,24902299, wiecej-zabytkowych-tramwajow-rusza-w-miasto-w-tym-roku-az-trzy.html (8.01.2020).

Kołakowski, T. (2010). Zabytki techniki i przemysłu. W: E. Lonc, S. Toczek-Werner (red.), Atrakcyjność przyrody i turystyki na Ziemi Watbrzyskiej (s. 174-169). Wałbrzych: Wydawnictwo Państwowej Wyższej Szkoły Zawodowej im. A. Silesiusa.

Kołodziejczyk, K. (2011). Historia, stan i perspektywy wykorzystania w turystyce dziedzictwa wrocławskiej komunikacji tramwajowej. W: K. Widawski (red.), Turystyka kulturowa na Dolnym Ślasku - wybrane aspekty. Tom 2 (s. 119-150). Wrocław: Instytut Geografii i Rozwoju Regionalnego Uniwersytetu Wrocławskiego.

Kołodziejczyk, K. (2014a). Rozwój oferty turystycznych linii kolejowych północnej Walii. W: S. Tanaś, J. Mokras-Grabowska (red.), Warsztaty z Geografii Turyzmu. Tom 4: Od autentyczności do komercji - o doświadczaniu w turystyce (s. 139-158). Łódź: Wydawnictwo Uniwersytetu Łódzkiego. DOI: https://doi. org/10.18778/7969-138-8.10

Kołodziejczyk, K. (2014b). Oferta turystycznych linii autobusowych przewożących rowery w Republice Czeskiej. Transport Miejski i Regionalny, 11, 27-34.

Kołodziejczyk, K. (2018). Potencjał polskich miast pod względem zabytkowych tramwajów i ich wykorzystanie w turystyce. Ekonomiczne Problemy Turystyki, 2 (42), 209-224. DOI: https:// doi.org/10.18276/ept.2018.2.42-20

Kołodziejczyk, K. (2019). Zabytkowa Linia Tramwajowa we Wrocławiu - analiza oferty turystycznej z punktu widzenia turystyki miejskiej. Turyzm/Tourism, 29 (1), 25-36. DOI: https:// doi.org/10.18778/0867-5856.29.1.03

Kowalczyk, A. (2005) Nowe formy turystyki miejskiej. Prace i Studia Geograficzne, 35, 155-197.

Kowalczyk, A., Derek, M. (2010). Zagospodarowanie turystyczne. Warszawa: Wydawnictwo Naukowe PWN.

Krejner, P. (2019). Zabytkowe tramwaje wrócity na wrocławskie torowiska. Pobrane z: https://radiogra.pl/zabytkowe-tramwaje-wrocily-na-wroclawskie-torowiska.html (8.01.2020).

Kruczek, Z. (2011). Atrakcje turystyczne. Fenomen, typologia, metody badań. Kraków: Wydawnictwo Proksenia.

Kubisa-Ślipko, A. (b.r.). Słownik wyrazów obcych. Wałbrzych: Wydawnictwo Aneks.

Kucharski, J., Kikin, A. (2010). Działania na rzecz ochrony historycznego taboru tramwajowego w Krakowie. W: E. Wyka (red.), Biuletyn Muzeum Inżynierii Miejskiej w Krakowie (z. 3) (s. 41-47). Kraków: Muzeum Inżynierii Miejskiej w Krakowie.

Lew, A. (1987). A framework of tourist attraction research. Annals of Tourism Research, 14 (4), 553-575. DOI: https://doi. org/10.1016/0160-7383(87)90071-5

Lipińska, I. (2011). Turystyka dziedzictwa kulturowego - wybrane aspekty ochrony prawnej parku kulturowego. Turystyka Kulturowa, 3, 14-27.

Lubka, A., Stiasny, M. (2010). Atlas tramwajów. Poznań: Kolpress. Lundberg, D. (1985). The Tourist Business. Nowy Jork: Van Nostrand Reinhold.

Matczak, A. (1989). Problemy badania funkcji turystycznej miast Polski, Funkcja turystyczna. Acta Universitatis Lodziensis - Turyzm, 5, 27-39.

Mehring, A. (2017). Komunikacja miejska w obsłudze obiektów turystycznych i rekreacyjnych. Progress. Journal of Young Researchers, 1, 84-95. DOI: https://doi.org/10.4467/25439928 PS.17.007.6513

Meyer, B. (2009). Historyczne i współczesne znaczenie transportu w turystyce. Problemy Transportu i Logistyki, 7, 149-159.

Meyer, B. (2011). Modyfikacja funkcji pełnionych przez podstawowe formy obsługi ruchu turystycznego. Ekonomiczne Problemy Turystyki, 16, 9-24. 
Meyer, B. (2015). Transport jako atrakcja turystyczna. W: B. Meyer (red.), Obstuga uczestników turystyki i rekreacji. Wybrane aspekty (s. 173-177). Warszawa: Difin.

Middleton, V.T.C. (1996). Marketing w turystyce. Warszawa: Polska Agencja Promocji Turystyki.

Mikos von Rohrscheidt, A. (2008). Turystyka kulturowa. Fenomen, potencjat, perspektywy. Gniezno: Milenium.

Mikos von Rohrscheidt, A. (2010). Regionalne szlaki tematyczne: idea, potencjat, organizacja. Kraków: Proksenia.

Nitkiewicz-Jankowska, A. (2006). Turystyka przemysłowa wizytówką górnośląskiego okręgu przemysłowego. Prace Instytutu Górnictwa Politechniki Wrocławskiej, Studia i Materiaty, 32 (117), 251-256.

Nowacki, M. (1999). Atrakcje turystyczne, dziedzictwo i jego interpretacja - jako produkt turystyczny. Problemy Turystyki, $22(2), 5-12$.

Nowacki, M. (2012). Atrakcje turystyczne: koncepcja, stan, determinanty zadowolenia osób zwiedzających. Poznań: Akademia Wychowania Fizycznego.

Nowacki, M. (2014). Zarządzenie atrakcjami turystycznymi w świetle aktualnych badań. Folia Turistica, 31, 31-52.

Page, S. (1995). Urban tourism, Londyn-Nowy Jork: Routledge.

Pawlikowska-Piechotka, A. (2009). Zagospodarowanie turystyczne i rekreacyjne. Gdynia: Novae Res.

Płocka, J. (2009). Wybrane zagadnienia z zagospodarowania turystycznego, cz. I. Toruń: Wyd. CKU.

Prideaux, B., Carson, D. (red.) (2011). Drive tourism: Trends and emerging markets. Londyn-Nowy Jork: Routledge. DOI: https:// doi.org/10.4324/9780203880395

Rogalewski, O. (1979). Zagospodarowanie turystyczne. Warszawa: Wydawnictwa Szkolne i Pedagogiczne.

Sielicki, T. (2012). Przez wroctawskich ulic sto... Historia tramwajów we Wrocławiu. Wrocław: Muzeum Miejskie Wrocławia.

Sielicki, T. (2013). Historyczny tabor komunikacyjny we Wrocławiu. Wrocław: Centrum Badań nad Miastem (maszynopis).

Smith, S. (1994). The tourism product. Annals of Tourism Research, 21 (3), 582-589. DOI: https://doi.org/10.1016/01607383(94)90121-X
Stasiak, A. (2006). Produkt turystyczny - szlak. Turystyka $i$ Hotelarstwo, 10, 9-40.

Stasiak, A. (2007). Szlaki turystyczne - zagospodarowanie, atrakcja czy produkt turystyczny? W: P. Kuleczka (red.), Szlaki turystyczne a przestrzeń turystyczna (s. 45-53). Warszawa: ZG PTTK.

Stasiak, A. (2013) Produkt turystyczny w gospodarce doświadczeń. Turyzm/Tourism, 23 (1), 29-38. DOI: https://doi. org/10.2478/tour-2013-0012

Styperek, J. (2002). Linearne systemy penetracji rekreacyjnej. Poznań: Wydawnictwo Naukowe Bogucki.

Swarbrooke, J., Page, S. (2001). Development and Management of Visitor Attractions. Londyn: Routledge. DOI: https://doi. org $/ 10.4324 / 9780080494500$

Widawski K., Duda-Seifert M. (red.) (2014). Turystyka przemysłowa w kontekście rozwoju zrównoważonego. Wrocław: Instytut Geografii i Rozwoju Regionalnego Uniwersytetu Wrocławskiego.

Wolniewicz, Ł. (2019). Więcej kursów na Zabytkowej Linii Tramwajowej. Pobrane z: http://wroclawskakomunikacja.pl/ raporty-przeglad/65-zmiany-w-rozkladach-jazdy/1612-wiecej-kursow-na-zabytkowej-linii-tramwajowej (8.01.2020).

Wójcik, J. (2012). Stan, wykorzystanie i zagospodarowanie obiektów poprzemysłowych w Wałbrzychu i Boguszowie-Gorcach, ze szczególnym uwzględnieniem budynków i budowli pogórniczych. W: K. Widawski (red.), Turystyka kulturowa na Dolnym Śląku - wybrane aspekty. Tom 2 (s. 97-117). Wrocław: Instytut Geografii i Rozwoju Regionalnego Uniwersytetu Wrocławskiego.

Żurawicz, J. (red.) (2013). Tramwaje w Polsce. Łódź: Księży Młyn Dom Wydawniczy.

Artykuł wpłyną: 28 stycznia $2020 \mathrm{r}$. Zaakceptowano do druku: 24 czerwca 2020 r. 